\title{
An Insight into the Interrelation between the Mosques' Architectural Codes and the Quality of Worshipers' Presence of the Heart: A Case Study of the Safavid Mosques in Isfahan
}

\author{
Mahdieh Ahmadi1, Hero Farkisch2², Vahid Ahmadi3, Ahmad Mirza Kouchak Khoshnevis ${ }^{4}$
}

1 Phd Candidate, Department of Architecture, Mashhad Branch, Islamic Azad University, Mashhad, Iran. 2 Assistant Professor.Department of Architecture, Mashhad Branch, Islamic Azad University, Mashhad, Iran. 3 Assistant Professor, Department of Architecture, Mashhad Branch, Islamic Azad University, Mashhad, Iran. 4 Assistant Professor, Department of Architecture, Iran Culture Heritage, Tehran, Iran.

(Received 21 Oct 2020, Accepted 18 Jan 2021)

The mosque is, and will stay as, one of the key and vital elements in the Islamic culture. It plays a great role in all aspects of worshiping, praying, creating a society, solving social problems, and establishing a Godruled government. In fact, the mosque is the soul in the body of its place and religion, and it is unfeasible to separate the soul from the body. The design of the traditional mosques was in such a way that the architects and artists, in addition to using special architectural techniques, used all the then-available art techniques to build a mosque whose components would calm the worshipers and lead them to strengthen their beliefs. In this work, the Safavid architecture, one of the legendary periods in Iranian and Islamic architecture, was selected and was researched with a special emphasis on the existence of a common denominator in the design of the earlier traditional Iranian mosques. The objectives of this study are hence: a) to identify, describe and explain the physical component system of the code on the individual's presence of the heart, and b) to identify the physical mindfulness components in the mosques architecture, and c) to identify the main characteristics of the famous mosques. In order to achieve these objectives, the researchers generally should seek to answer two main questions: what are the mysterious components of traditional Iranian mosques specifically? And what are the main physical components of the Safavid mosques for ensuring the mindfulness and the presence of the heart of individuals? In the present study, a mixed exploratory method is used. The effect of mosque's physical component system and each component's signification on the presence of the heart in the Safavid mosques were investigated in detail for answering the two questions above. According to the "Likert scale", two types of questionnaires were designed. Then, a multi-criteria decision-making method alongside the "Seca classification method" were used to study the interrelation between the aforementioned components and their effects in the following Isfahan's mosques: Imam Mosque as the only asymmetrical mosque in the world that is the summary of the traditions and patterns at its period of construction; and Sheikh Lotfollah Mosque which lacks any courtyards or minarets; Hakim Mosque, which have many mihrabs and interesting brickworks inside; and AghaNoor Mosque as the masterpiece of the period. Our findings show that there is a significant interrelation between the elements of physical component system with the presence of the heart and mindfulness of the prayers and masses. Therefore, respecting all the elements of the physical component system altogether would increase the mindfulness and the presence of the heart in masses of prayers, leading to the creation and strengthening of the architectural patterns in harmony with human needs and expectations in important religious places. This, in turn, will lead to the recreation of Islamic-Iranian architectural patterns, having a tremendous impact on the development and deepening of religious values in masses and boosting the motivation of worshipers to continue attending the mosque.

Keywords: Mosque, Presence of the heart, Architectural codes, Safavid mosques of Isfahan, Physical component system.

\footnotetext{
${ }^{*}$ Corresponding author. E-mail: hero.farkisch@mshdiau.ac.ir
} 


\title{
DOI: $10.29252 /$ ciauj.5.2.51
}

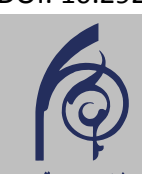

\section{بازشناسى رابطهُ رمزَّان معمارى مساجد و كيفيت حضور قلب}

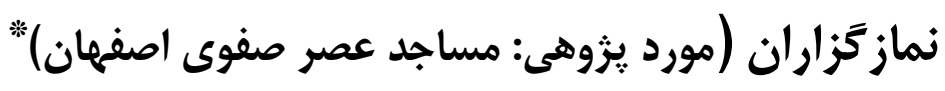

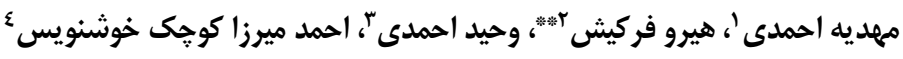

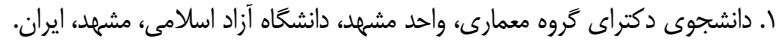

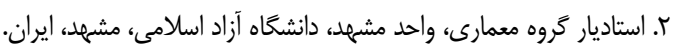

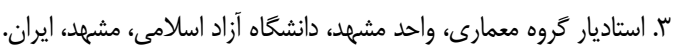

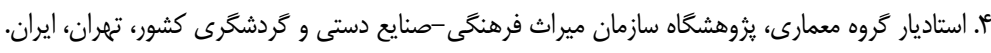

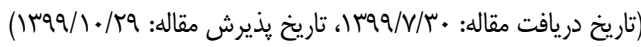

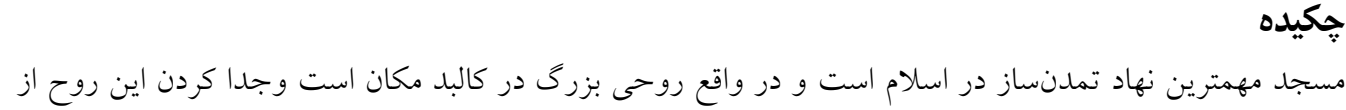

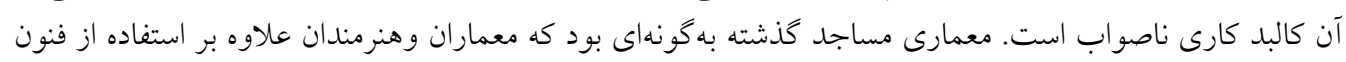

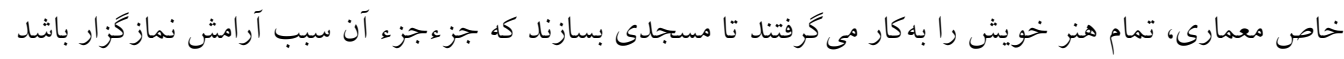

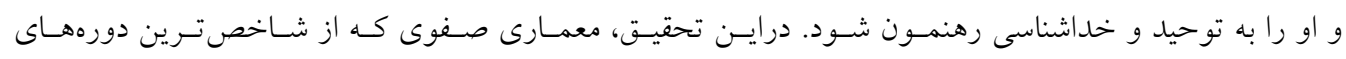

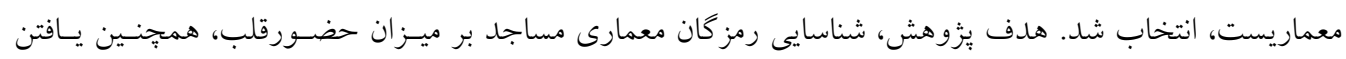

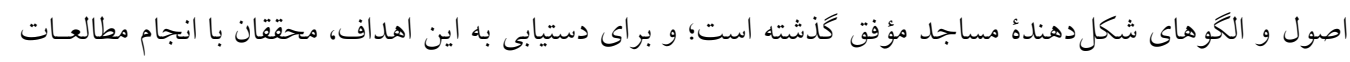

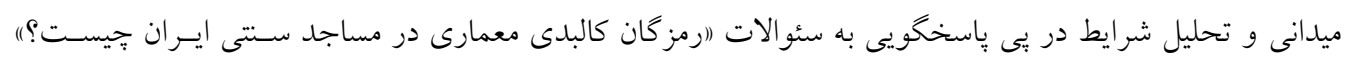

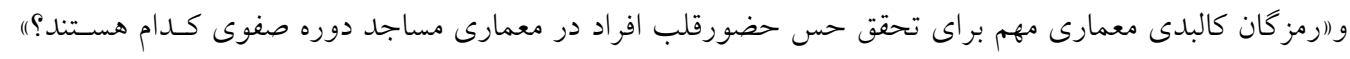

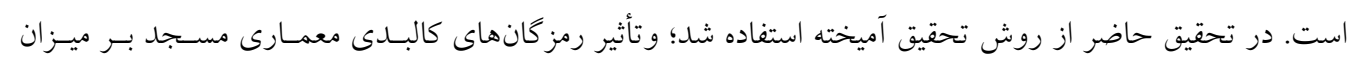

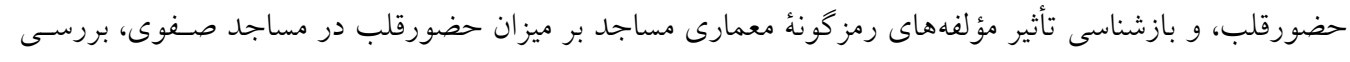

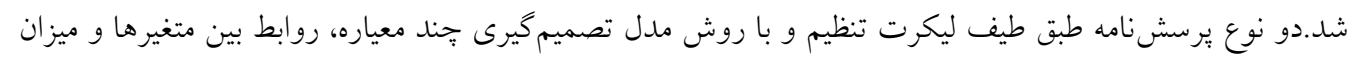

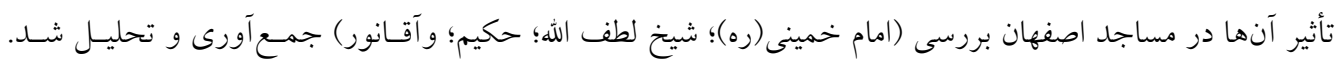

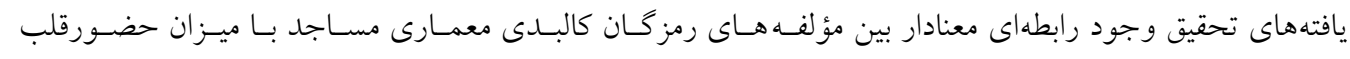

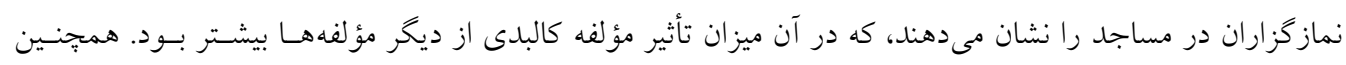

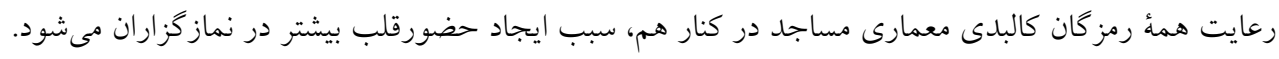

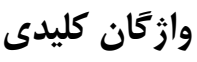
مسجد، حضور قلب، رمز كان معمارى، مساجد صفوى اصفهان، نظام كالبدى.

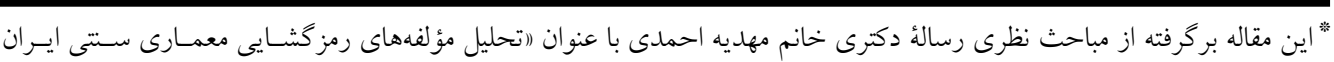

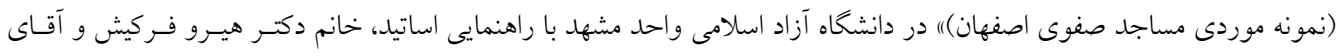

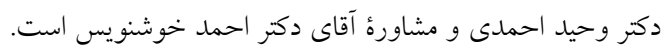
hero.farkisch@mshdiau.ac.ir : 


\section{مقدمه - مق}

راهبردهايى براى افزايش حضور افراد در مساجد ارائه شود. معمارى امروز بهويزه معمارى مساجد، متتقل كندأ معانى تمانى

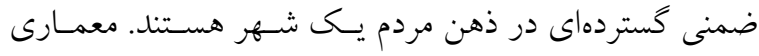

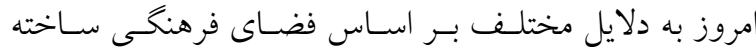
نمىشود. در قرآن كـريم وازٔه مســد بيست و دو دو بـار، وازٔه

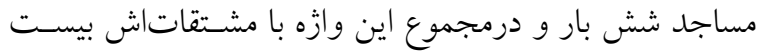

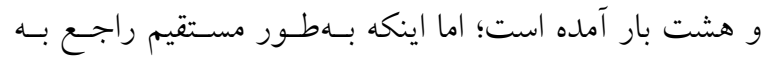

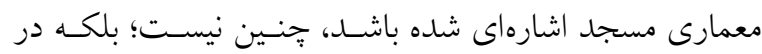

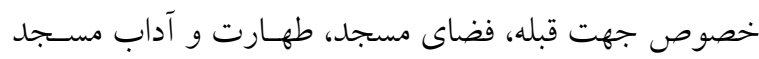

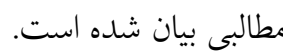
ساخت بناهاى غنى و ارزشمند كه علاوه بر رفع نيازهاى

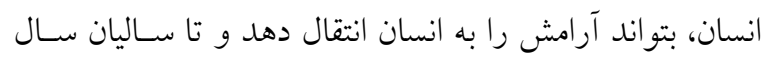

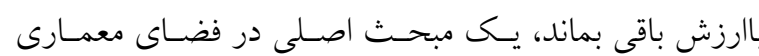
امروز كشور است. علت اصلى انتخاب موضوع (ابررسى تـأثير

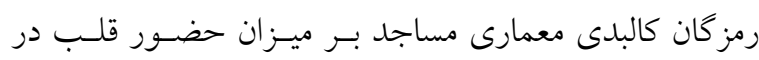

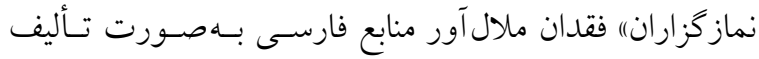

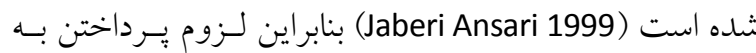
موضوع مقاله كاملاً مشهود است. وجه نو آورى مقالهُ حاضر، نسبت به مطالعات بيشـين بـهـ لحاظ موضوعى، كاملاً مشخص است و تاكنون ايسن موضسوع به طور مستقيم بررسى نشده است تا با درس گيرى از تجارب

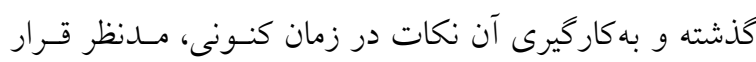
كَيرد؛ در اين يُزوهش، ابتدا رمز كان كالبدى معمـارى مسـاجد

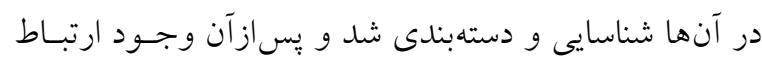

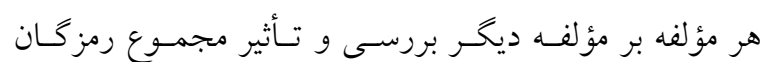

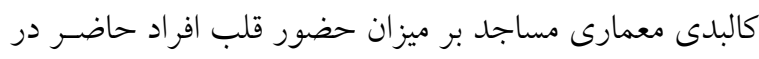

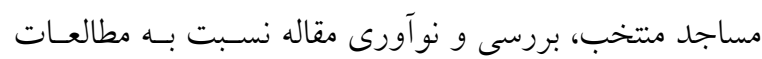

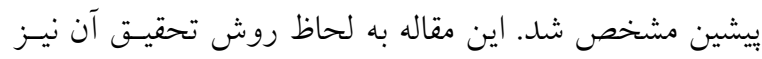

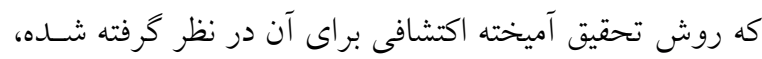

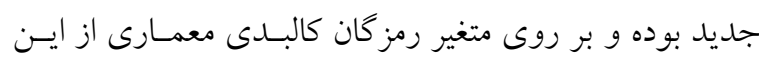
روش بهره كرفته شده است.
نماز، جشمهُ زلال نورانيت و معنويـت اسـت و هـر مسـلمان

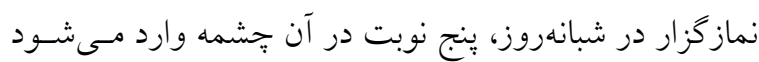

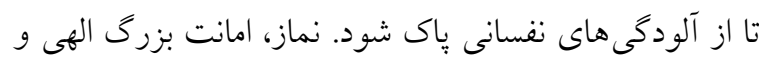

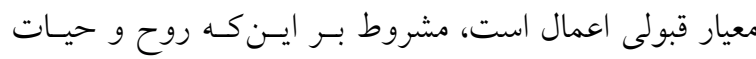
داشته باشـد، روح نمـاز حضـور قلـب و توجـهـ بـه معبـود و خشوع در برابر او است. نماز بدون حضور قلب همانند بيكـر بى روح است. معيار قبولى نماز نيـز، حضـور قلـب نمــازگزار

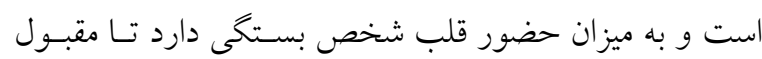

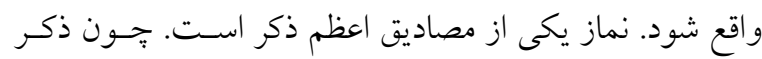

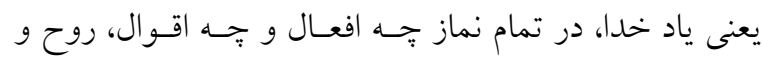
جان نماز همان حضور قلب است كه حقيقـت ذكـر اسـت و

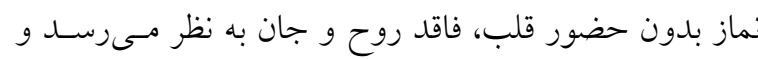

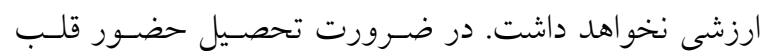
همين بس كه نماز بدون حضور قلب، نماز حقيقى نيست و

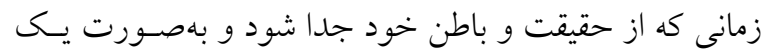

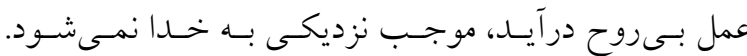
بنابراين، لزوم انجام بررسى و شناسايى عوامـل كالبــى مـؤثر

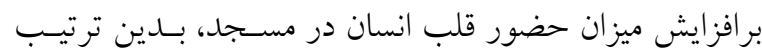

$$
\text { مشخص مىشود. }
$$

در اين مقاله، تلاش مى شود مبانى نظرى معمارى مساجد سلامى در دورةٔصفوى بررسى شود و رمزهـا و نمادهـاى بـهـ كاررفته در اين مساجد شناسايى شوند و رمز كشايى از رمـوز

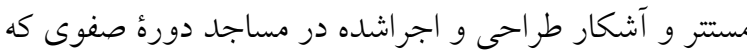
از دورههاى موفق به لحاظ ساخت ابنيــة ارزشــند در كشـور عزيز ايران است، صورت كيرد و همجنين "رمز كان ' كالبـدى معمارى مساجد)" و عوامل شكلدهندة آن و (حضور قلـب)" و

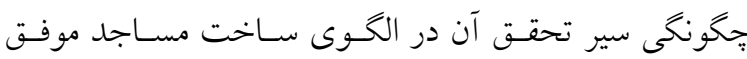

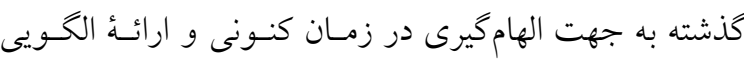
مناسب معمارى مساجد فعلى به جهت افزايش حضـور افـراد

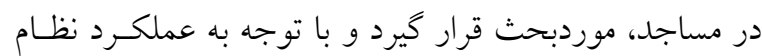
مقدس جمهورى اسـلامى ايـران در ايسن زمينـه، راهكارهـا و 
بازشناسى رابطة رمز كان معمارى مساجد و كيفيت حضور قلب نماززَزاران

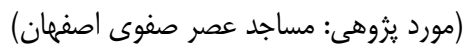

حضور قلـب افـراد در معمــارى مسـاجد دورة صـفوى كــدم

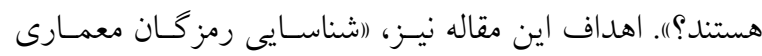
مساجد بر ميزان حضور قلـب) و همجنسين (يـافتن اصـول و الكوهاى شكل دهندة مساجد موفق دورة صفوى" است.

كالبدى مساجد بهصورت جزء جـزء بررسى شــند و مـورد

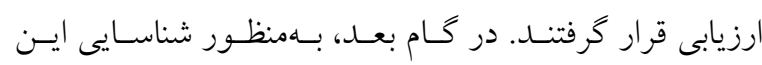

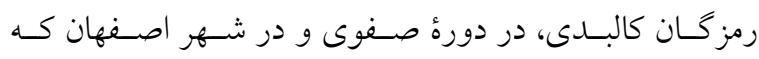

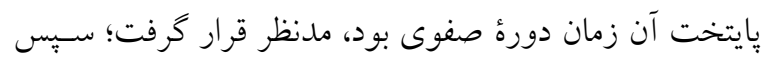

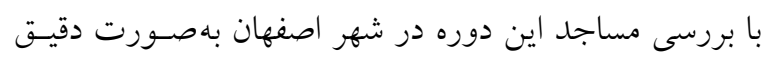

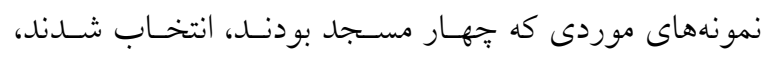
يس ازآن با حضور در مساجد منتخب، كه شامل مسـجد امـام

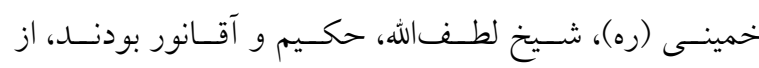

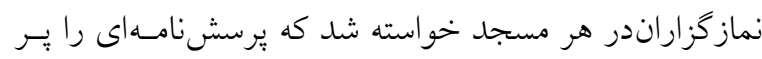

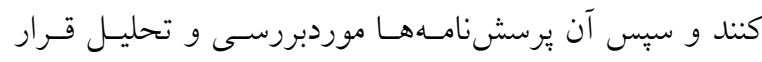

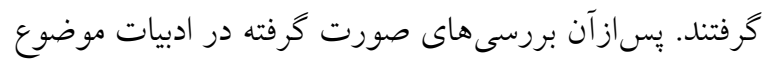

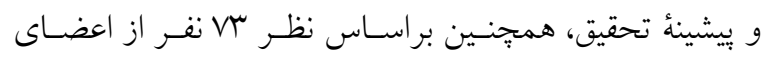

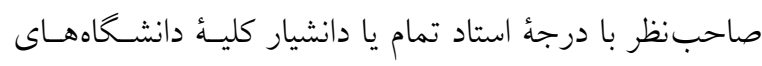
شهر تهران، مطالب جمع آورى شده بازنخرى شد و بــه تأييـد

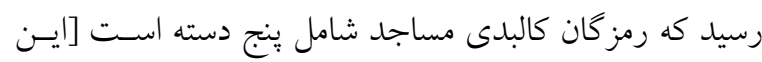
ينج دسته شـامل: مؤلفـه كالبـدى (نقـوش، تزئينـات، محتـوا،

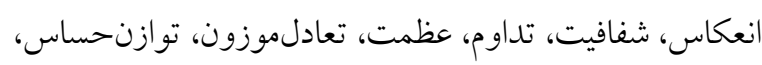

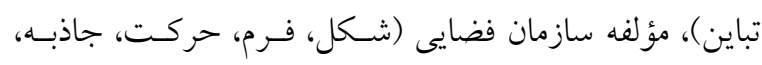

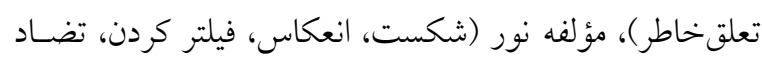

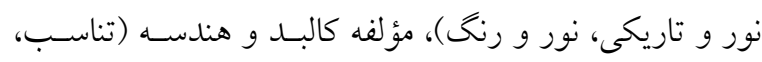

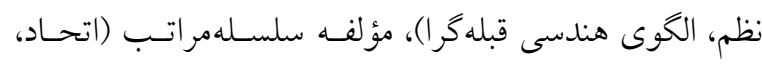

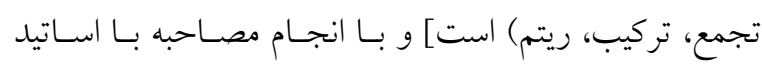

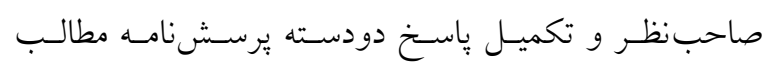
موردنياز يزوهش، دستهبندى و جمع آورى شد.

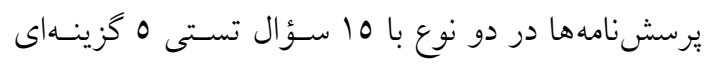

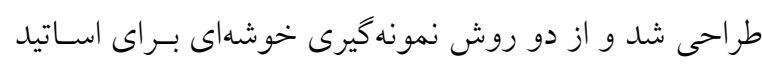

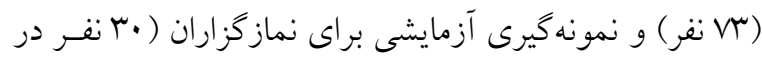

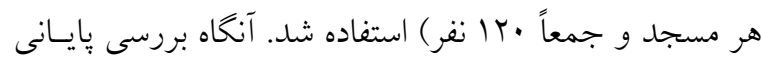

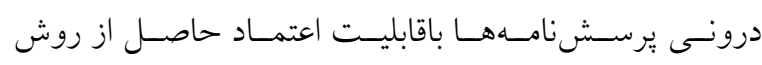

اين تحقيق در راستاى باسخغويى بـهـ يرسـشهـاى زيـر

"رمزكـان كالبــى معمــارى در مســاجد ســتى ايــران

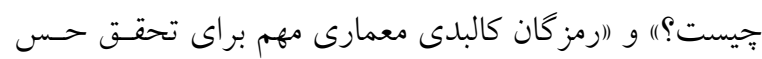

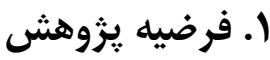

فرضيه يزوهش جزين است: (ابه نظر مىرسد رمز كان كالبـدى

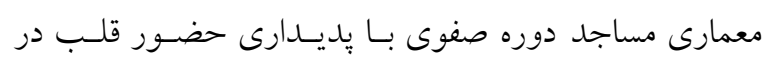
نماز كزاران، همخوانى معنادارى دارد)، در حقيقت، با شـناخت

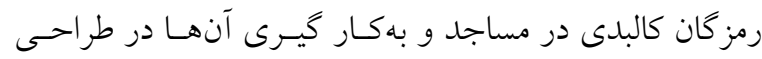
مساجد امروزى، افزايش حضور قلب در انسانهـا و نزديكى درى داني به خداوند بزرى، بهخوبى صورت مى گيرد.

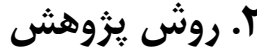

مقالة بيش روى، در خصوص كشف رمز كُان كالبدى معمارى

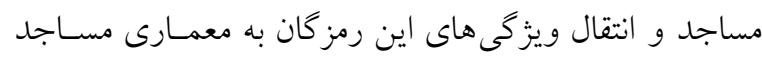

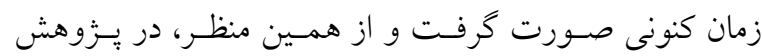

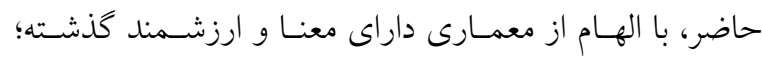
كشف رموز صورت گرفته، و به بسط و گسترش آن در زمان دان

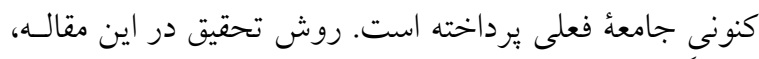

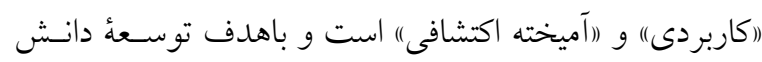

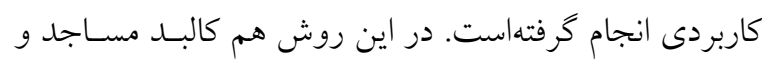

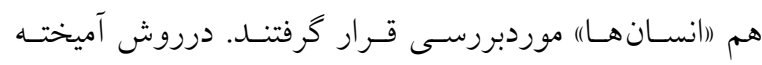
اكتشافى از نقاط قوت همهٔ رويكردها (توصيفى كيفى و كمّى،

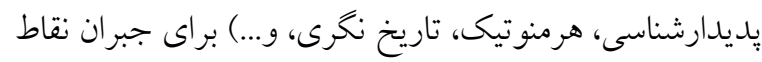

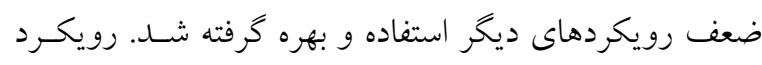

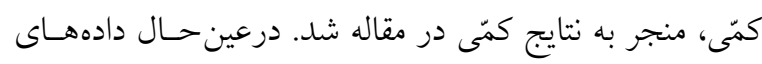

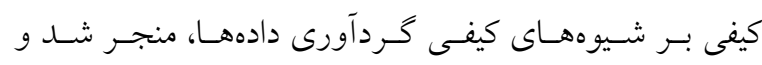
نخاههاى مختلف به موضوع رمز كان كالبدى معمارى مسـاجد

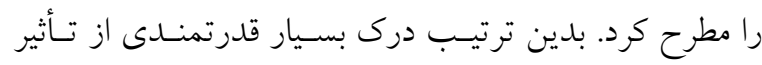

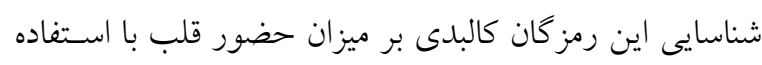
از كالبد بناى مسجد و جّكونكى ساختار آن اتفاق افتاد. در تحقيق حاضر براى سنجش فرضيه، جهار كام اصلى و مشخص برداشته شـــ. در مرحلـهُ نخسـت، عناصـر رمزكـان 
جدول ا: خلاصه نظريات در حوزه مبحث 》رمز "cod

Table 1: Summary of theories in the field of "code"

\begin{tabular}{|c|c|c|c|c|}
\hline نظريه يرداز & نظريه & \multicolumn{2}{|c|}{ طبقدبندى مطالعات در حوزهٔ رمز } & رديف \\
\hline رنه كُون (Y..r) & نماد و رمز، امرى سازگار با نيازهاى طبيعى بشر است و بر معانى رموز از منظر مابعدالطبيعى تأكيد & 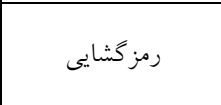 & \multirow{6}{*}{ نظريات حوزه } & 1 \\
\hline $\begin{array}{l}\text { آنانداكوماروسوامى } \\
(Y \cdot \mid V)\end{array}$ & آفرينش تمثيلات از صورتهاى مثالى، و درنتيجه هنر بازتابى از حقايق برتر الهى & حقايق برتر & & r \\
\hline $\begin{array}{l}\text { فريتهوف شووان } \\
\quad(r+10)\end{array}$ & نظم، سمبل مطلق و راز، نشانه بىنهايت است. كمال نيز از همنشينى نظم و راز زاده مىشود. & شكوه حقيقت & & r \\
\hline 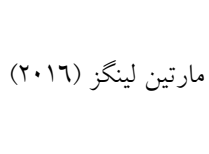 & رمز نشانهاى به مثال اعلاى خود & بزازگشت به به بهج مبدأ و & & $\varepsilon$ \\
\hline 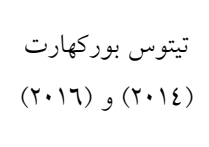 & معانى رمزى عناصر آثار هنرى، برگر فته از روح اسلامى و هنر دينى عبارت است از جهان مادى & كشف علت استفاده از & & 0 \\
\hline 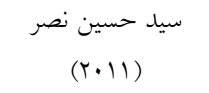 & رمز و عناصر رمزى تجلى امر وحدت در كثرت و سرجشمه هنر اسلامى در وجه درونى يا باطنى & رمز در هنر اسلامى & & 7 \\
\hline
\end{tabular}

اينكه تا امروز در خصوص بحث رمز گان موجود در معمـارى

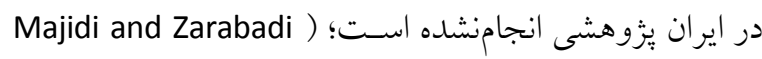

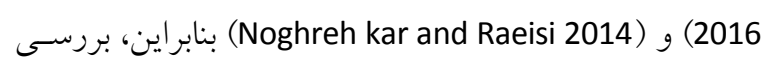

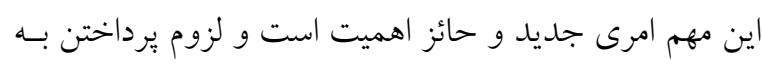
موضوع، كاملاً مشهود به نظر مىرسد.

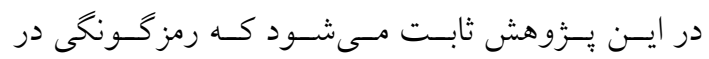
ييكرهبندى، فرمى جهاربعدى در مساجد است كـه عـلاوه بـر

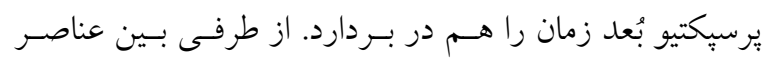

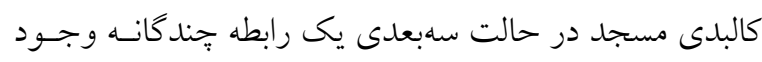
دارد و آن رابطه بيان مىدارد كه (بين عناصر كالبـدى وحــدت وجود دارد و با كشف اين وحدت، رمزهــا بـــدهبـــردارى مسى شوندا). در ادامه به خلاصهُ نظرات صـاحبنظـران و محققـان خارجى و داخلىى، در خصوص موضوع رمزخـان در مسـاجد يرداخته مىشود. بر اساس بررسى و مرور سـابقه موضـوع در كتاب ها و يايانامهها، مشخص مى شـود كـه اغلـب منـابع در

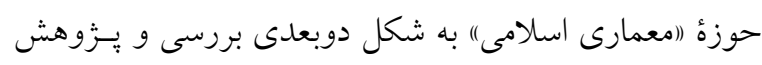

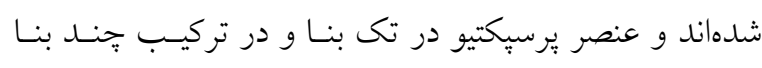

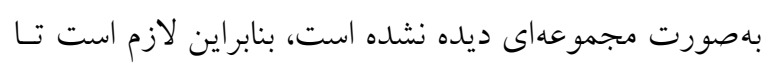
در يزوهشهاى جديد محققان ايسن موضـوع را مــنظر قـرار

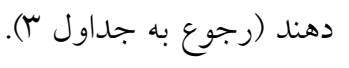

اندازه گيرى آلفاى كرونباخ براى برسشنامه اساتيد عـدد 91/.

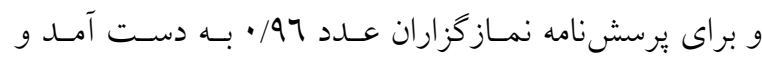

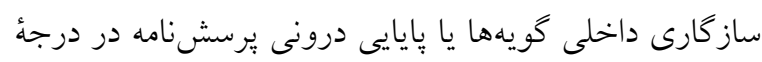
(اعالى" قرار گرفت. جهت جمع بندى و تحليل يرسشنامه بهـا، با رويكردى تحليلى از مدل تصميم گيرى جند معياره و نتـايج

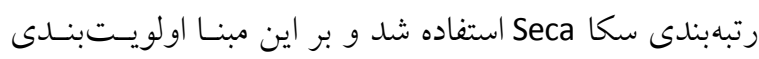
كزينها صورت يُّيرفت. سبّ با استفاده از نرمافزار كps16

$$
\text { نتايج استخراج شد. }
$$

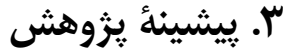

صاحبنظران و محققان زيادى گرايش به تبيين كاربرد مذهب اسلام در معمارى داشتهاند؛ اما درزمينه كشف رمز گان موجود در معمارى ايران، بهويزه دورهُ ورود اسلام به كشـور بـهــور خاص و جحكونكى كشف اين مهم و انتقال آن بـه معمـاران و نظريه يردازان آينده، خلأ تحقيقاتى وجود دارد. در حال حاضر

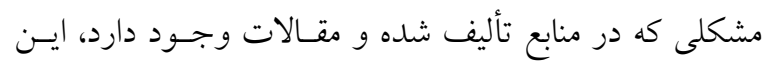

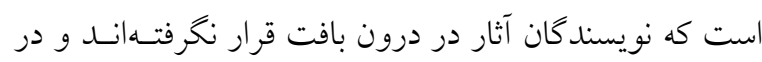

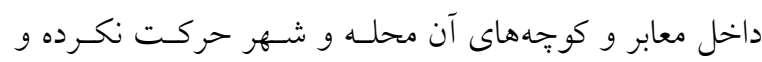

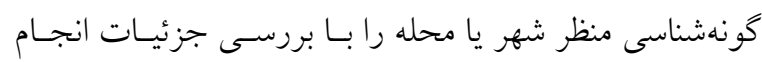

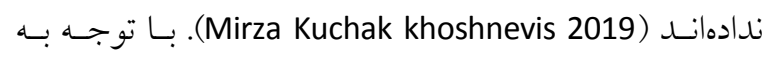


بازشناسى رابطة رمز كان معمارى مساجد و كيفيت حضور قلب نماززَزاران

(مورد يزولى: مساجد عصر صفوى اصفهان)

جدول r: خلاصه تحقيقات در حوزه مبحث "رمز "

Table 2: Summary of research in each area of "mystery"

\begin{tabular}{|c|c|c|c|c|}
\hline محقق & موضوعات تحقيق & وضوعات تحقيق در حوزة & 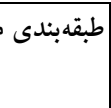 & رديف \\
\hline 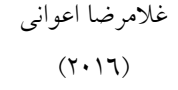 & دستهبندى انواع نماد و اهميت آن، شكل گيرى هنر اسلامى بر بايه نمادگر ايى، رمز امر حقيقى و وجودى & نمادكرايى اساس خلقت & \multirow{6}{*}{ | } & 1 \\
\hline 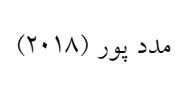 & حضور و ظهور حقيقت در هنر مسيحى، عامل تمايز و جدايى از هنر يونانى-رومى و توجه به تعادل و & 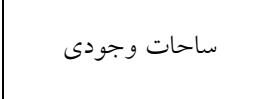 & & r \\
\hline $\begin{array}{l}\text { عبدالحميد نقرهار } \\
\quad(Y \cdot \mid \varepsilon)\end{array}$ & وجود رابطه بين رموز با محتوا و بطن اسلام و رمز گشايى در آثار معمارى، تحققى نسبى & رمز كُشايى نسبى & & $r$ \\
\hline 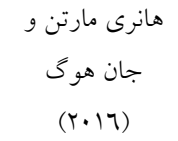 & صورت و معناى هنر اسلامى مبتنى بر باورى از هستى و خارج از مكان و زمان & بالاترين مرتبه تجلى هنر، & & $\varepsilon$ \\
\hline 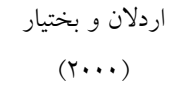 & بررسى معمارى ايرانى -اسلامى و تأثير تصوف و سمبوليسم و رمز كشايى معمارى سنتى ايران & 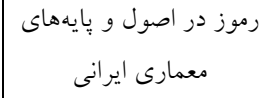 & & 0 \\
\hline رجبعلى مظلومى (10) & آشنايى با مفاهيم عميق عرفانى و حكمى جون رمز و نقش آينه بهعنوان كامل ترين رمز معرفتى & هنر اسلامى رمزى از بهشت & & 7 \\
\hline
\end{tabular}

و حسديث و تـأثير آن در معمـارى اسـلامى، ديخــى (اجنبـــ عملكردى" و توجه به جنبـهُ مطالعـاتى و تحقيقـاتى موضـوع (ابازشناسى رابطه رمزكان معمارى مسـاجد و كيفيـت حضـور قلب نماز گزاران) و تأثيرى كه بر معمارى كنـونى كشـور مسى

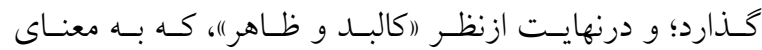
بهرهمندى از الخوهـا و آرايسههـاى هندسىى، در جــارههـا و و يوستهاى ساختمان به جهت تأمين زيبايى، سازه و همجنسين سايهبان است. به دليل كسـتردگى ايسن جنبـههـا و بـهـ جهـت

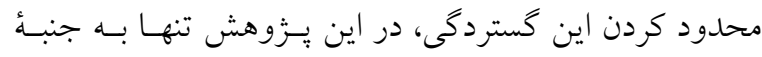
(اعملكردى) و (اكالبد و ظاهر) "يرداخته خواهد شد (رجوع بـه.
مطالعـات صـورت گرفتـه درزمينـهُ معمــارى مســاجد، مشخص مى كند كه اكثر فعاليـتهـاى بـهـكاررفتـه در بناهـاى معمارى اسلامى مخصوصاً معمارى ايرانى، از نوعى هندسه و تناسبات، هم بهصورت نمايان و هم بهصورت ينهان در درون

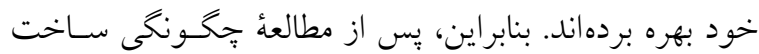

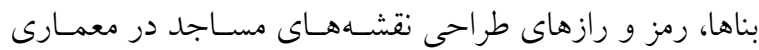

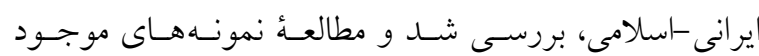
درزمينه (بررسى تأثير رمز كان كالبدى مساجد بر ميزان حضور قلب در نماز گزاران) مشخص مى كند كه سه جنبهُ مهم در اين زمينه وجود دارد، نخست (جنبة اعتقادى) و نخاه ويزه به قرآن

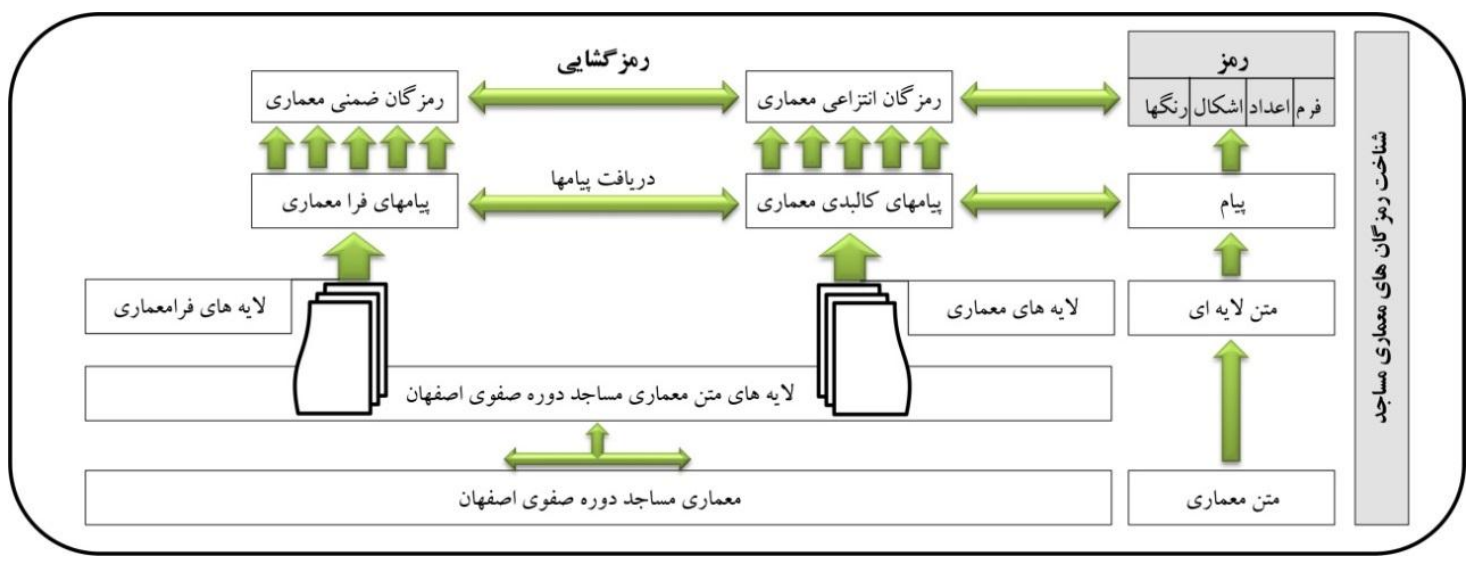

تصوير (: عوامل مؤثر در رمزگشايى معمارى مساجد دوره صفوى)

Fig. 1: Effective factors in deciphering the architecture of Safavid mosques 


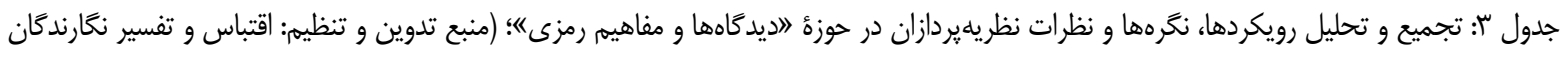

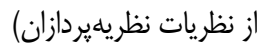

Table 3: Summary and analysis of approaches and opinions of theorists in the field of "cryptographic concepts"; (Adaptation and interpretation of authors from the theories of theorists)

\begin{tabular}{|c|c|c|c|c|}
\hline تجميع نظرات نظريهيردازان & خلاصه نظريه مطرحشده & نام نظر يه برداز & |تقسيمبندى نوعاه & رديف \\
\hline \multirow{2}{*}{ 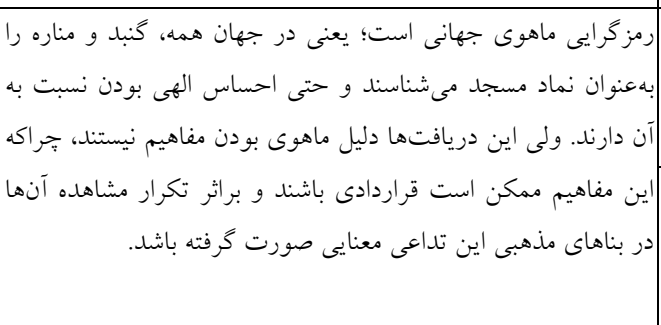 } & | & 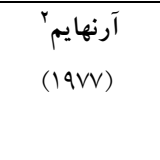 & \multirow[t]{4}{*}{ ديدكاه ماهوى } & \multirow{7}{*}{ 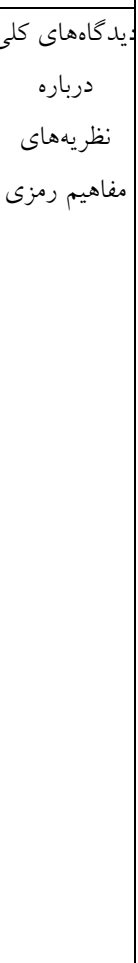 } \\
\hline & | & كارل يونگ & & \\
\hline \multicolumn{2}{|c|}{ 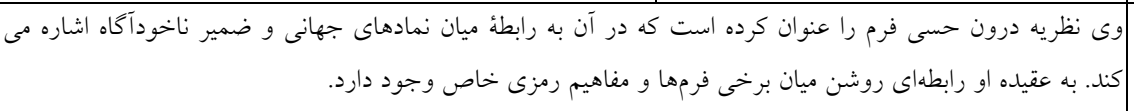 } & آن آن تينگ & & \\
\hline \multicolumn{2}{|c|}{ 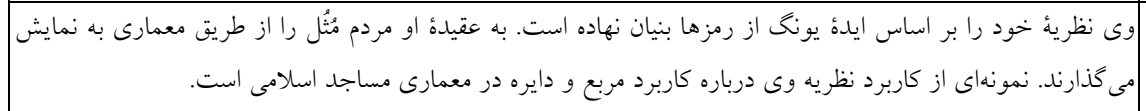 } & $\begin{array}{l}\text { كلر كوير } \\
\text { (19V7) }\end{array}$ & & \\
\hline 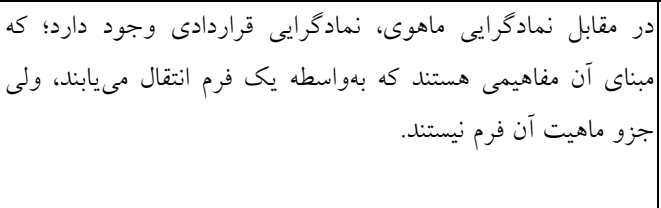 & 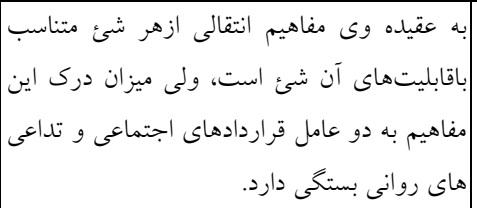 & (1999) & يا قراردادى اكتسابى & \\
\hline \multicolumn{2}{|c|}{ 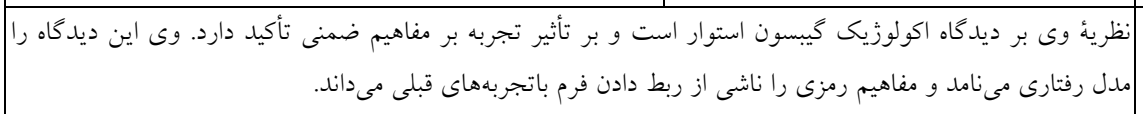 } & 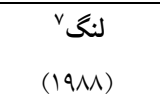 & & \\
\hline \multicolumn{2}{|c|}{ 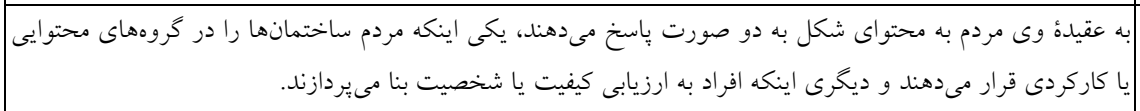 } & $\begin{array}{l}\text { (1997) } \\
\text { (197اسار) }\end{array}$ & & \\
\hline
\end{tabular}

يرداختهانــ (Kabir Saber et al. 2014) همجنــين در مطالعـهُ نمودار (1).

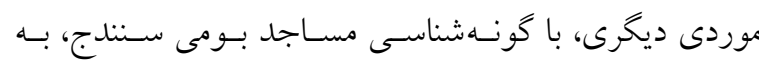
تفاوتهاى عناصـر كالبـدى معمـارى مســاجد ايسن منطقـهـ و

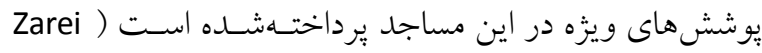

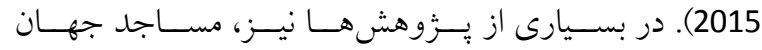

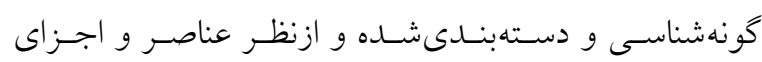

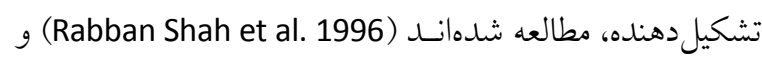
(Eismail Nejad et al. 2012)

.(Grube 2011)

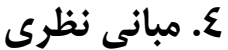

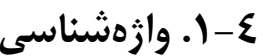

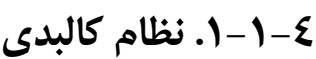

در مساجد عبارت است از دسته امورى كه در طراحى فضـاى له كالبدى مساجد جهت ايجاد حس قداسـت و افـزيش ميـزان

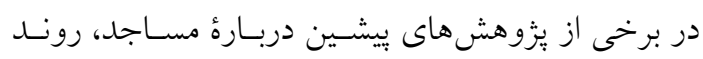

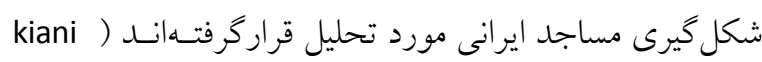
2000) و در بررسى ديخر، بناهاى اسلامى و ازجمله مسـاجد، بامطالعه مقايسهاى اجزاى كالبدى نخستين مساجد ايرانى بـر

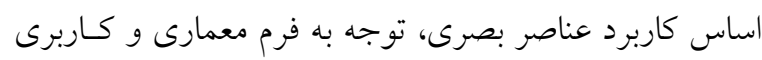
آنهــا دسـتهنـــــى و بررسـى شــــ (Hillenbrand 1976).

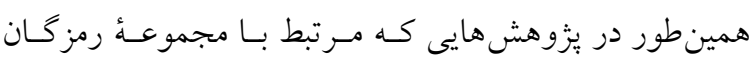
كالبدى معمارى مسـاجد بـود، ايسن مجموعسه را شـامل يــنج زيرمجموعه در نظر كرفتند (Ahmadi et al.2020)، همجنـين در برخى از تحقيقات، با تأكيــ و تمركـز بـر برخسى مسـاجد معروف ايران، شاخص هاى معمارى و سازهاى مساجد مطالعه شدهاند (Hojjat and Maleki 2012). برخسى نيـز بـا در نظـر

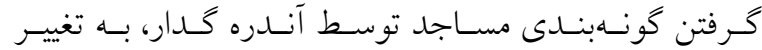
شــكلهــاى كالبـدى مســاجد و بيـــايش و تكامـل آنهــا، 
بازشناسى رابطة رمز كان معمارى مساجد و كيفيت حضور قلب نماززَزاران

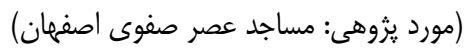

سازندة آن، نقش مهمترى نسبت به تكتيك اجـزا دارد. بـراى

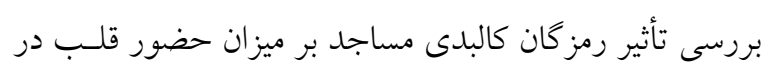

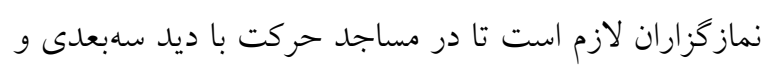

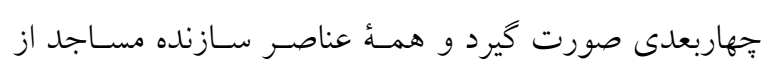

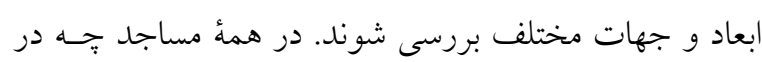

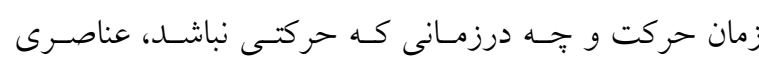

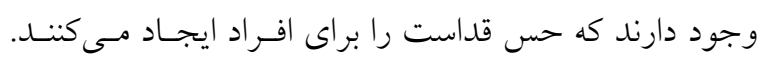

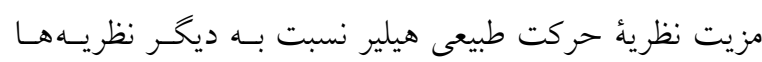

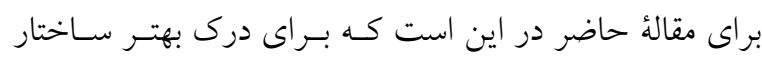

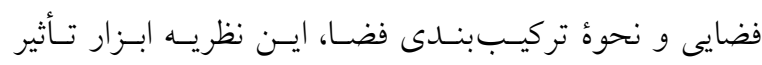

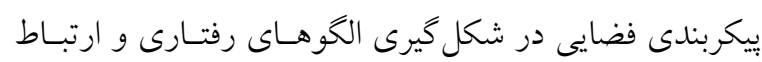

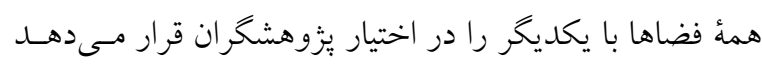

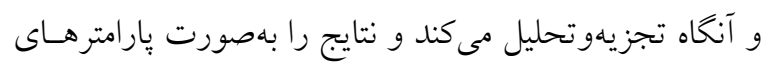

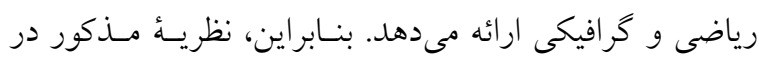
اين مقاله به كار كرفتهشده است (رجوع به به نمودار (Y) (Y).

\section{ه. مورد يزوهى؛ مساجد صفوى منتخب اصفهان}

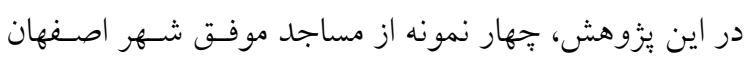

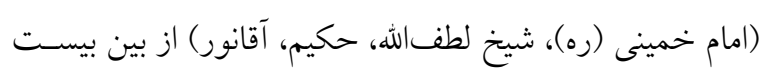

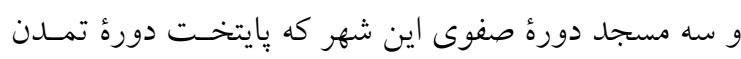

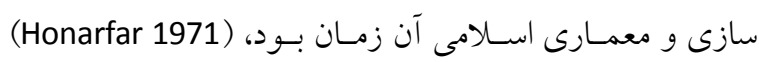

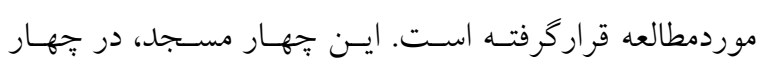
موقعيت مختلف استقرارى در زمان صفوى قـرار داشـته و در

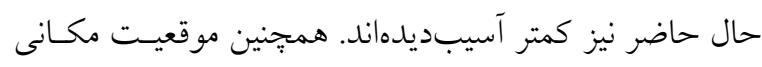

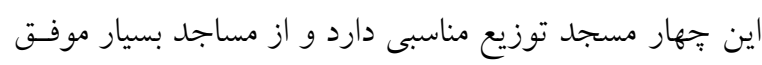

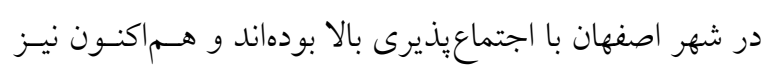

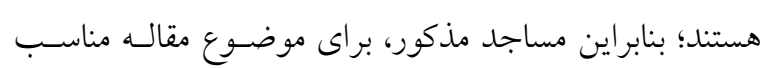

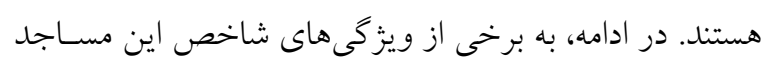

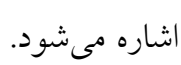

\section{*مسجد امـام خمينـى (ره)؛ در اصـفهان يــ نمونـــ}

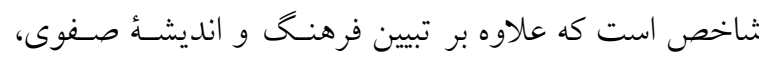

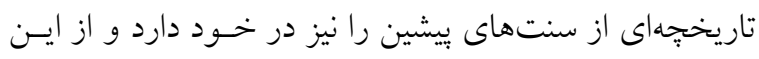

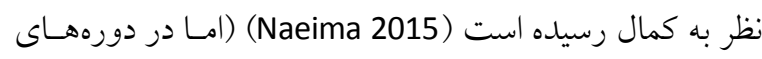

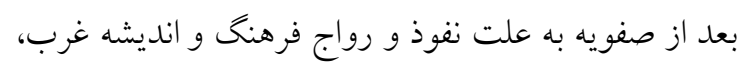

حضور قلب كه هدف اصسلى طراحسى مسـاجد اسـت، بـراى

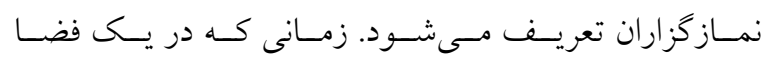

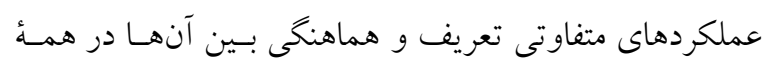

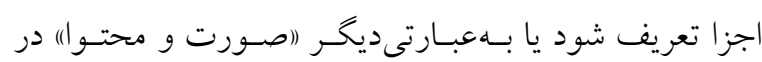

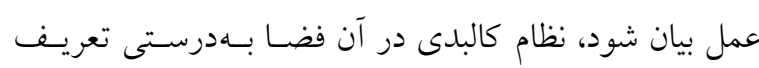

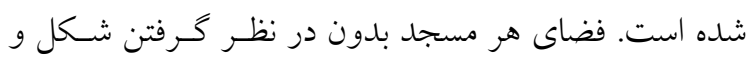

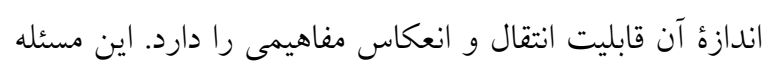
زمانى غليظتر مىشود كه فرهنخ غنى ايران و معمارى سنتى،

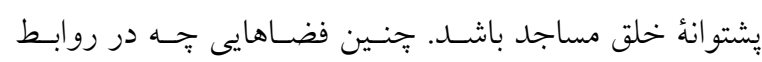

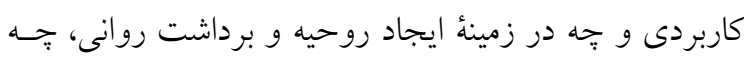

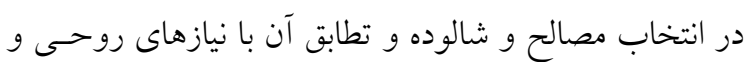
روانى غنى مىشود (Ahmadi et al.2020).

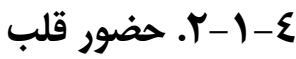

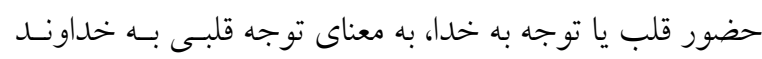
و احساس وجود او در همهجا اسـت، بـهـونسهاى كـه همـواره

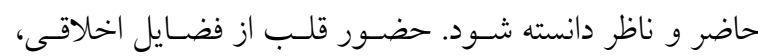
روح همه عبادات و از شرايط كمـال عبـادات محسـوب شـاته

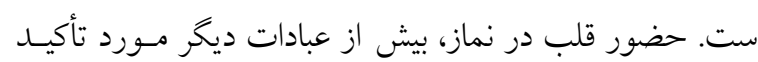

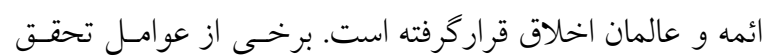

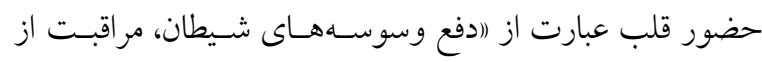

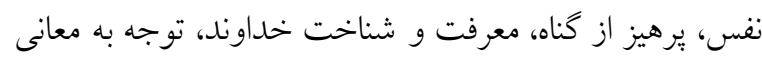
عبادات نماز و كتترل قوه خيال)، است (Majlesi 2016).

\section{ع-r.}

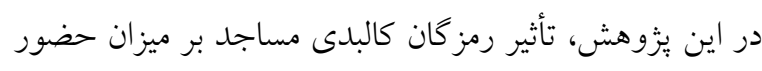

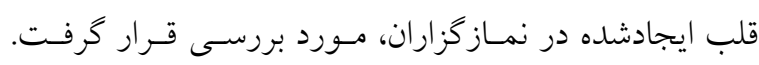

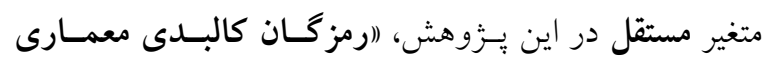
مساجد) (مؤلفههاى كالبدى، سـازمان فضـايى، نسور، كالبـد و

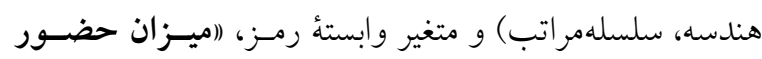
قلب نمازگزاران) است. در اين يزوهش، از نظريـهُ (احركـــ

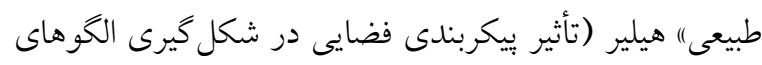

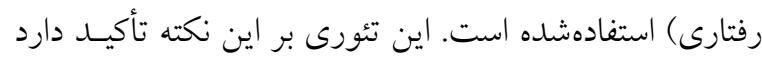

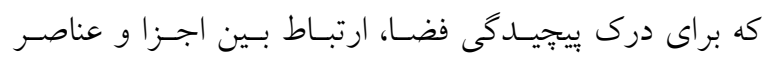




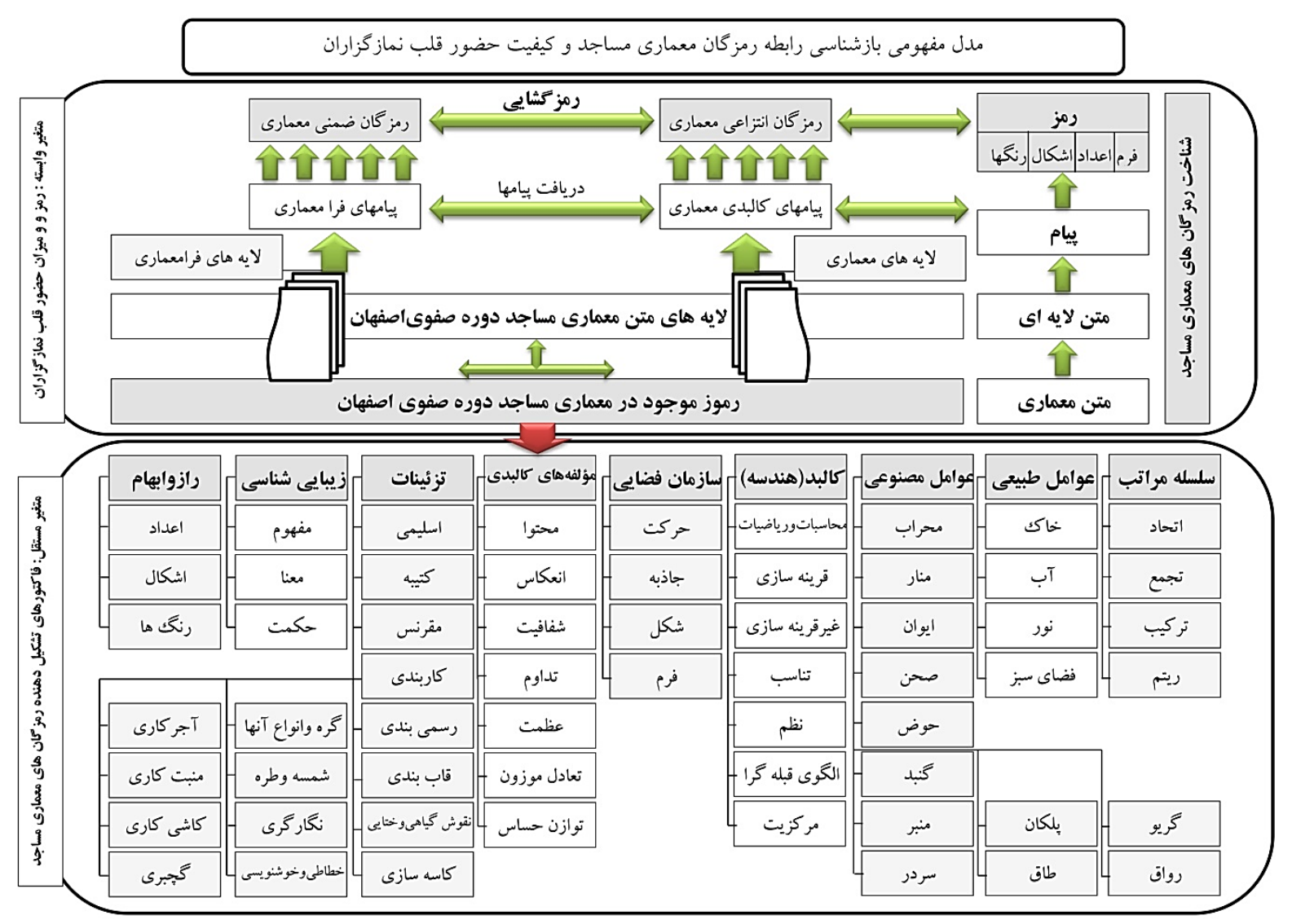

تصوير ז: مدل مفهومى بررسى تأثير رمز كان كالبدى معمارى مساجد بر ميزان حضور قلب در نمازكزاران

Fig. 2: Conceptual model to study the effect of physical codes of mosque architecture on the presence of heart in worshipers

بناى بى نظير نكاسته است. (Zarei 2010). اين مسـجد صـحن

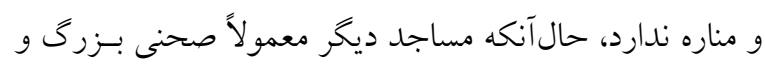

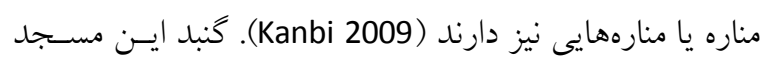

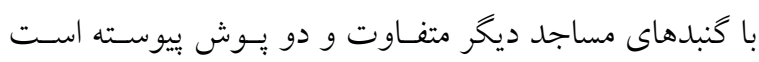

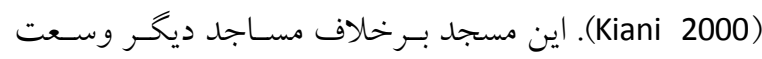

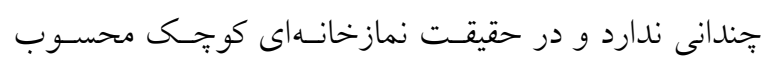

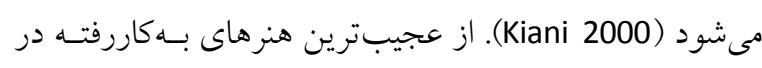

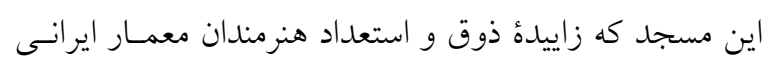

است، حل مشكل قبله در اين مسجد است (Godar 1999).

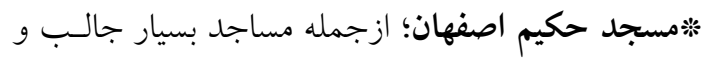

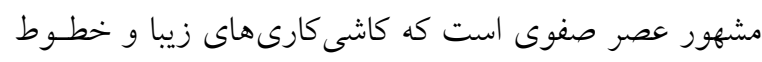

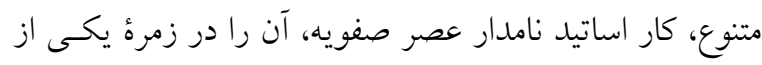

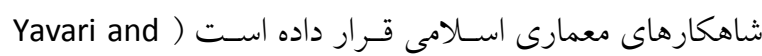

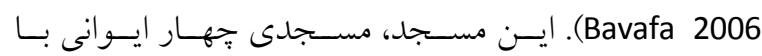

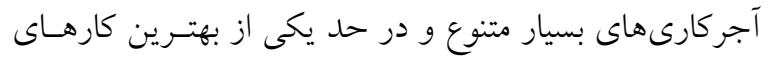

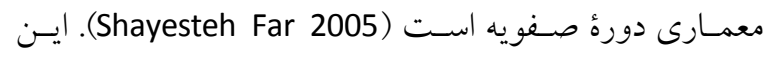

ماهيت صورتهاى تزئينى تغيير مى كند كـه در تعاقـب آن، از

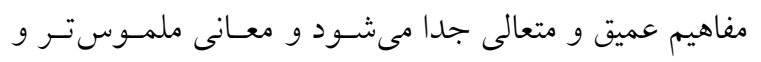

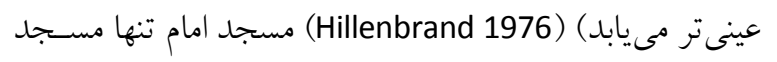

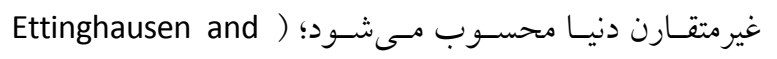

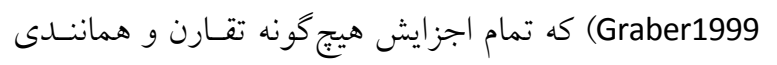
ندارنـــ (Amir Hosseini 1954) و ) Turkmen Khameh 2003) بنابراين، اين مسجد بهعنوان يكى از نمونههـا انتخـاب شد. *مسجد شيخ لطفالله؛ نسبت به ساير مسـاجد صفوى

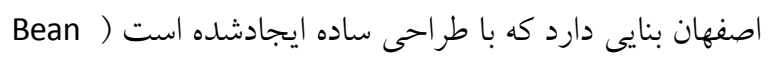

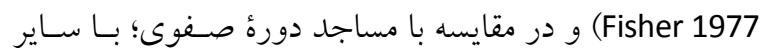

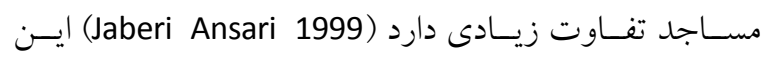
تفاوت، به دليل نداشتن برخسى عناصـر معمـارى در سـاختار

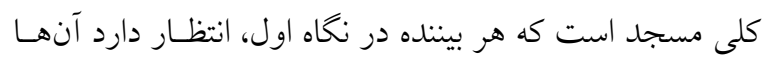
Rafiei Mehrabadi ) رادر خجنين بناى اسلامى باشكوهى بيبند

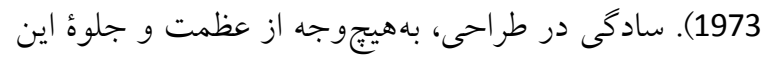


بازشناسى رابطة رمز كان معمارى مساجد و كيفيت حضور قلب نماز زَزاران

(مورد يزوهى: مساجد عصر صفوى اصفهان)

جدول عا: انتخاب و بررسى نمونه مساجد در شهر اصفهان

Table 4: Selection and examination of samples of mosques in each city of Isfahan

\begin{tabular}{|c|c|c|c|c|c|c|c|c|c|}
\hline تمايز & فضا & زيبايىشناختى & عوامل مصنوعى & طوامل & يلان & هندسه & نوع كاشى كارى & تاريخجه & مساجد \\
\hline تركيبى همخن از تريباً برونخراو & | ايجاد فضايى براى ارتباط انسان بان & و حجم بسيار عالى مشكلات & كَبد، جلوخان، & نور & 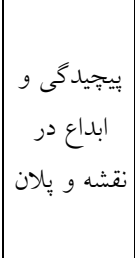 & 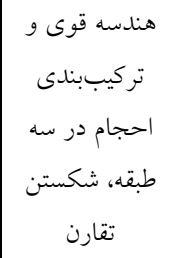 & | واشى كارى معرق & عباس اول & لمسجد \\
\hline كرد محن انحراف و حل & فكانيابى صحيح & 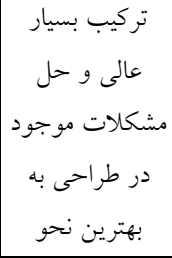 & كنبد، دو مهتابى، & بزرگ ون وض & جا گهند ايوانى & هندسه قوى & 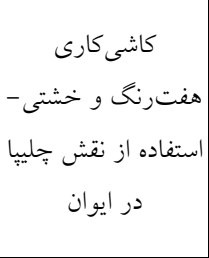 & | عباس اول|-1. & امام اصفهان \\
\hline 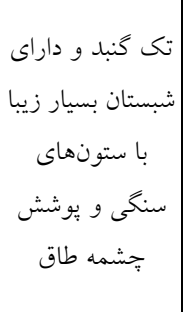 & صحيح فضاها & 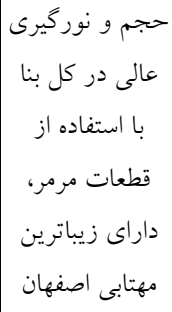 & دو دو محراب، & كوجى دوض & با خهار ايوانى & هندسه قوى و & خاشى كارى معرق و لاجوردى & 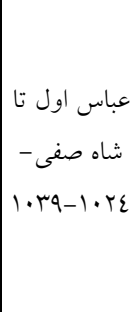 & مسانو \\
\hline م & مكانيابى صحيح & 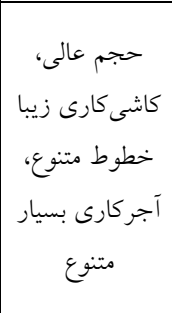 & 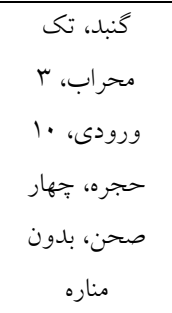 & 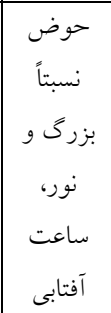 & با خهار ايوانى & تركيب & كاشى كارى معرق و & 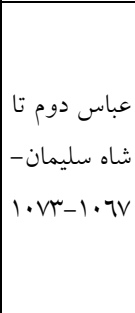 & مسجد \\
\hline
\end{tabular}

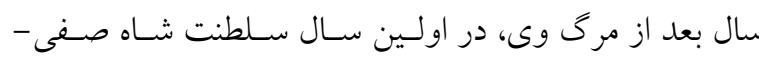

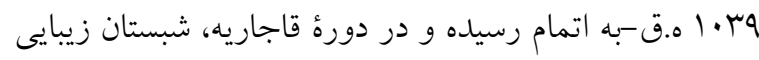

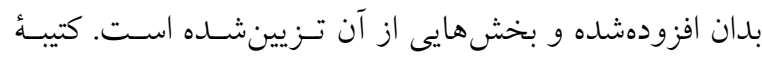

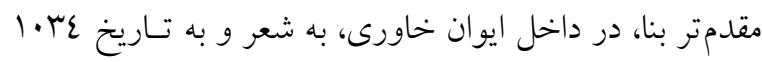
هجرى است (Honarfar 1971) بـر اسـاس مستن ايـن كتيبه،

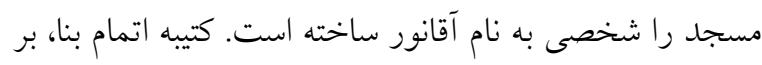

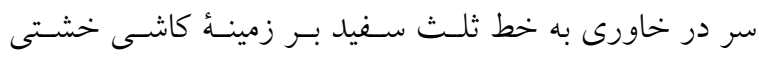

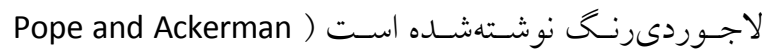

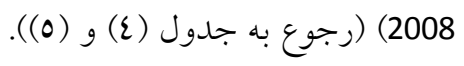

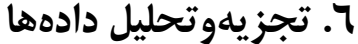

بر اساس نـوع مطالعه، اروش تحليـل اكتشـافى" بـراى ايسن

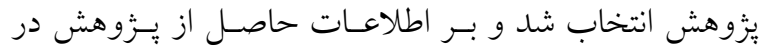

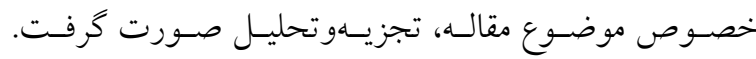

مسجد محر اببهاى متعلد و متنوع دارد كه هركدام نسـبت بـهـ

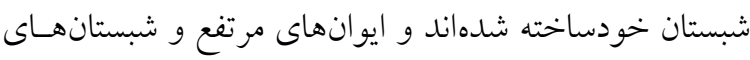

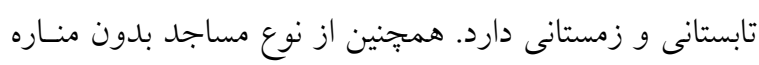
و كُبد برجسته و بزرگ است (Hillenbrand 2001). مسـجد حكيم از آخرين آثار دورةٌ صـفوى اسـت و شـايد از ديـدكاه يُزوهشكران غربى، در مقايسه با مسجد امام و شيخ لطف الله

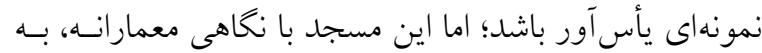

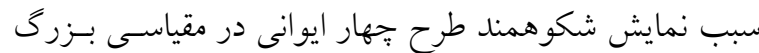

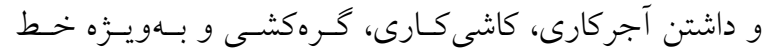

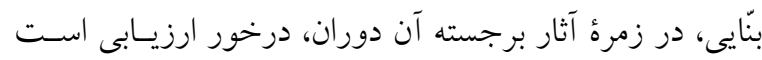

(Mesbahi 2009)

*مســـد آقــانور اصــفهان؛ ايـن مسـجد يكسى از شاهكارهاى معمارى عهل صفوى در اصفهان به شمار مىرود.

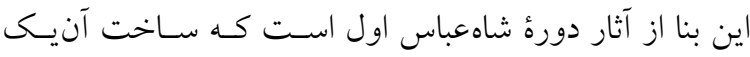


كتابخانــاى، انجـام مصـاحبه بــا اسـاتيد و صـاحبنظــــان، يرسش بامهها و بازديد ميدانى صورت گرفت و بهوسيلة آنهـا

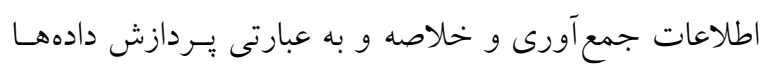

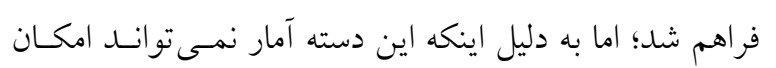
ارائهُ نتيجه گيرى فراتر از دادههاى مورد بيردازش را كـه شـامل

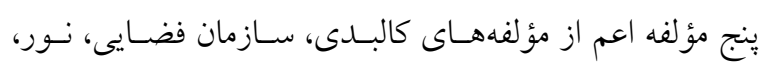
كالبد و هندسه و سلسلهمراتب است، در اختيـار محقـق قـرار

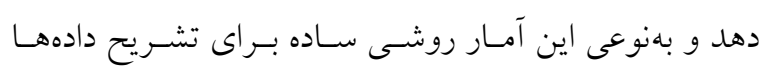

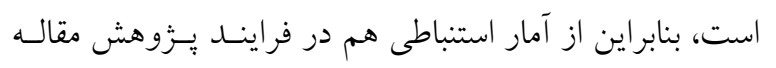

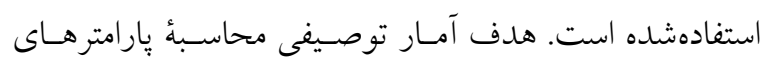

دودستهُ يردازش اصلى يعنى روش آمـار (اتوصسيفى") و آمـار

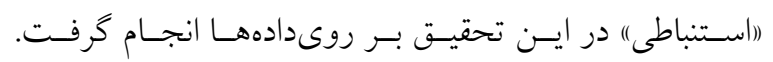

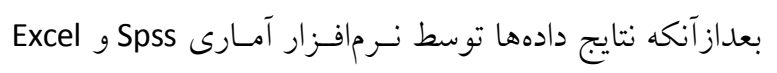

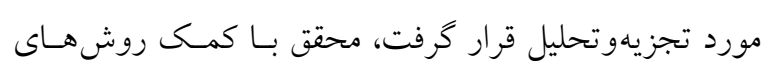

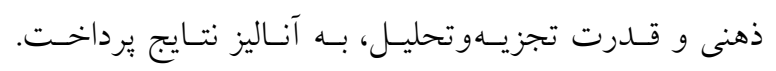
تجزيهوتحليل آمارى دادهها بهصسورت كمّى و كيفى انجـام

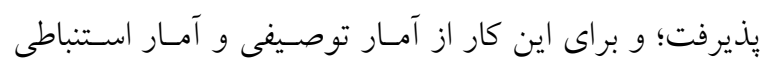
استفاده شد.

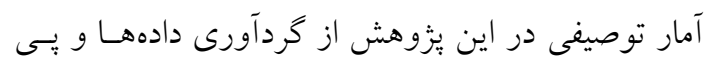
بــردن بـهـ ماهيـت مجموعـه دادههـاى حاصـل از مطالعـات

جدول ه: ياّان، نما، برش و سلبعدى مساجد منتخب

Table 5: Plan, facade, section and three dimensions of selected mosques

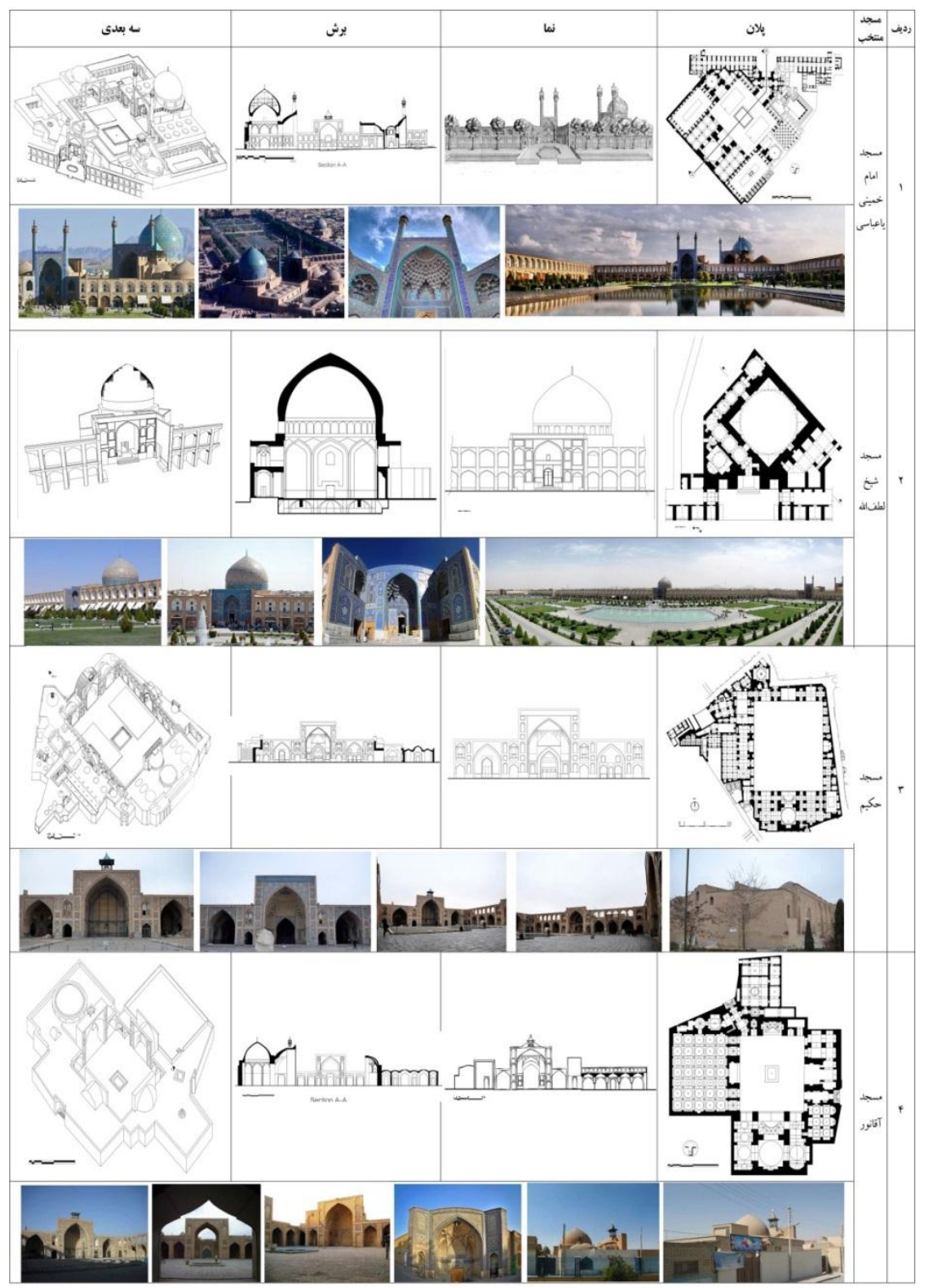

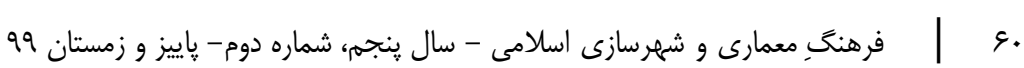


بازشناسى رابطة رمز كان معمارى مساجد و كيفيت حضور قلب نماز زَزاران

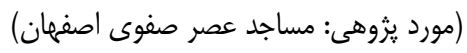

در داخل جهار مسجد منتخب و هم در قسمت بيرونى فضاى

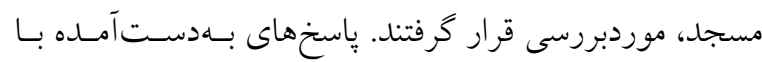

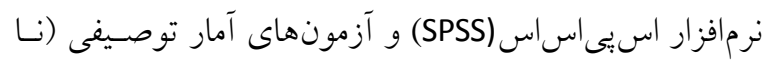

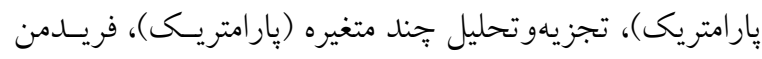

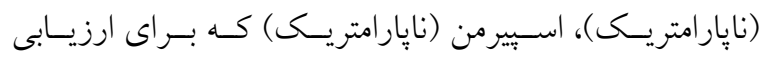

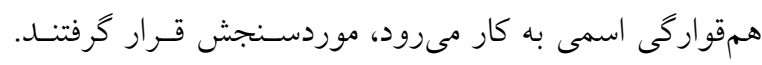

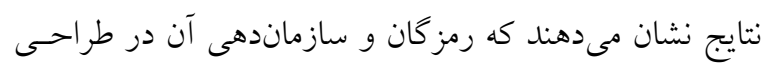

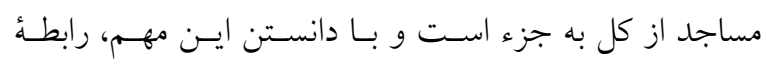
موجود ميان رمز كان و حضور قلب مشخص مى مشـود و ايسن

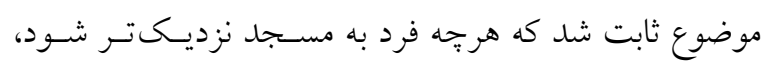

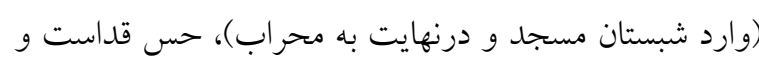
حضور قلب وى بيشتر و به خالق نزديكتر مى شود.

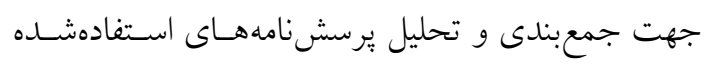

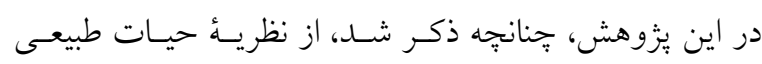

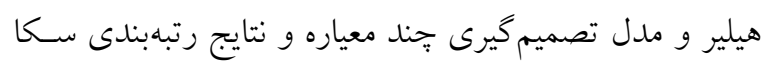

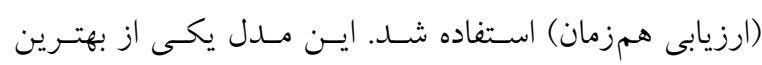

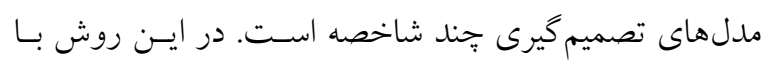

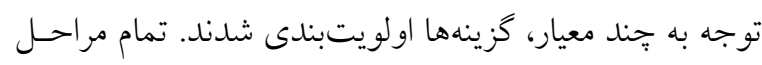

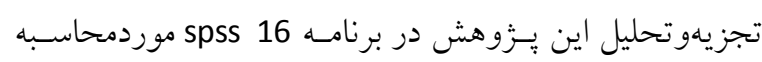
قرارگرفت. نتايج نشان داد كه مؤلفهُ كالبدى (نقوش، تزئينات، محتوا،

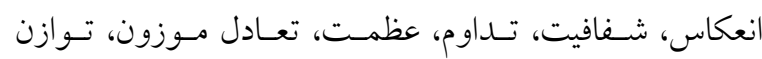
حساس و تباين) با وزن نسبى 100/• بيشترين اهميت را دارد

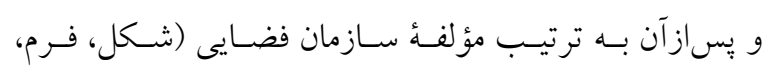

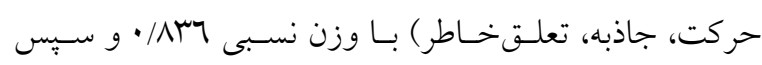

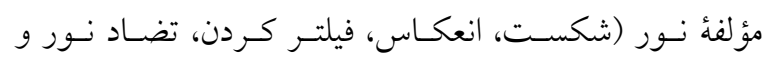

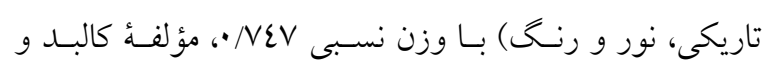

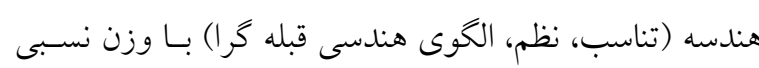

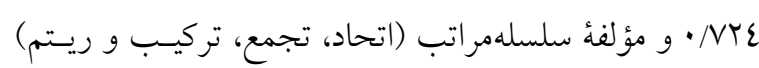

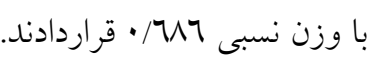

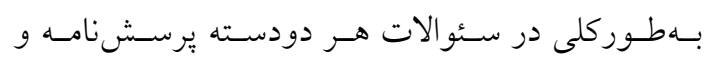

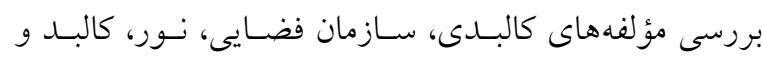

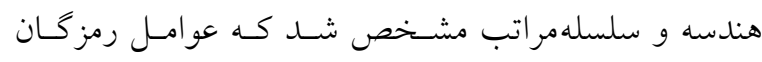

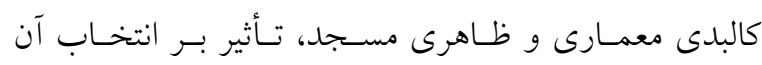

يزّوهش يعنى ينج مؤلفه است و با استفاده از سرشمارى

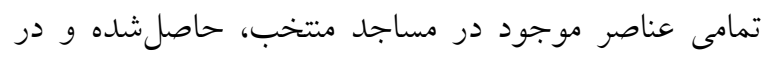

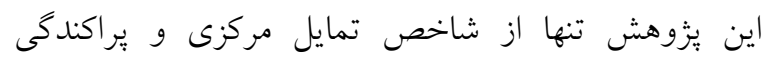

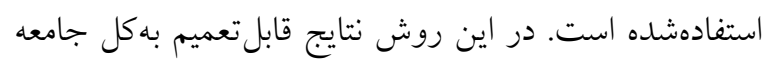

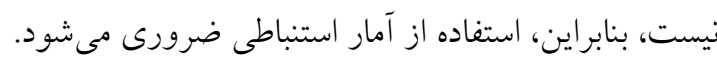

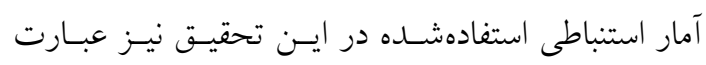

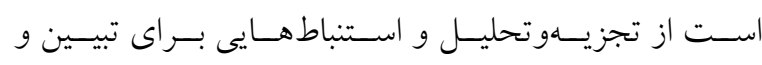

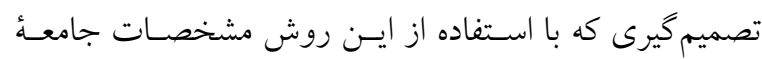

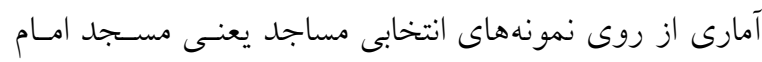

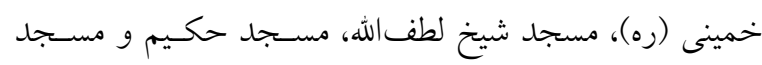

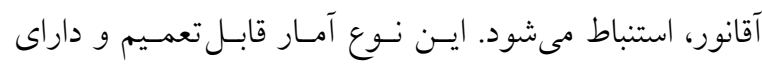

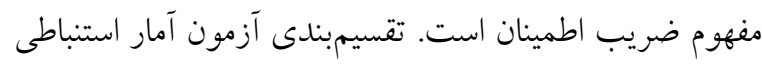

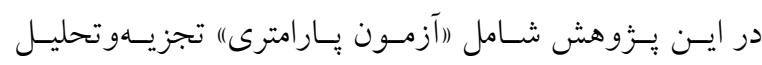
اطلاعات در سطح مقياس فاصلهاى و نسبى است كه حـــاقل

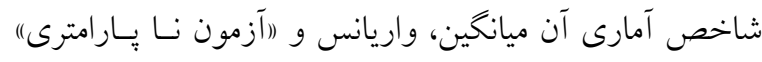

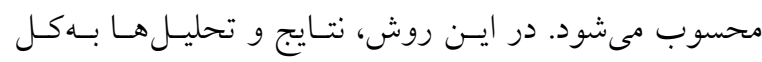

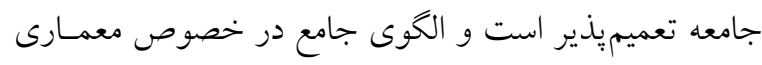
همأ مساجد توسط اين روش، حاصل مىشود.

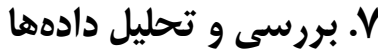

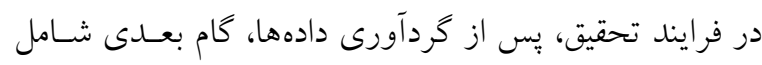

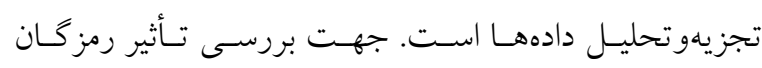

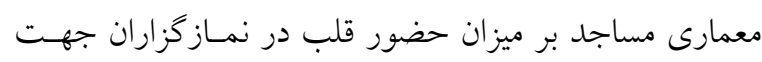
تحقق حضور حسداكثرى در مسـاجد، بيـان شــ كـه رمزخـان

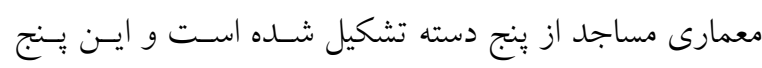

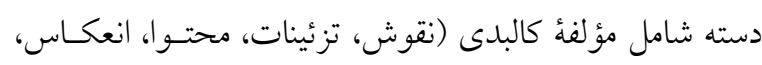

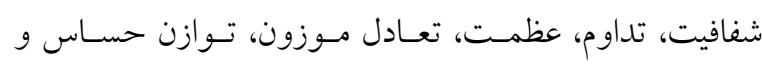

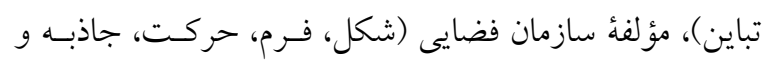

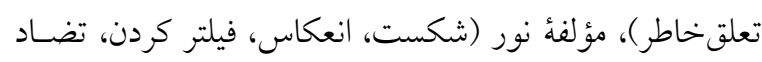

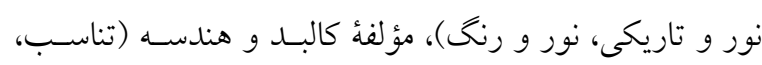

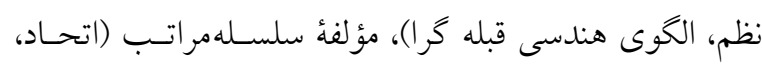

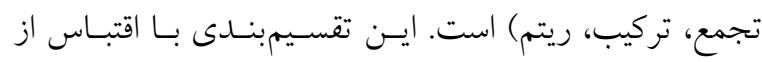

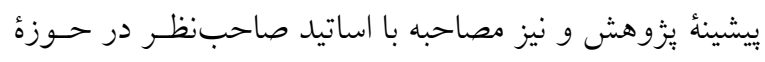

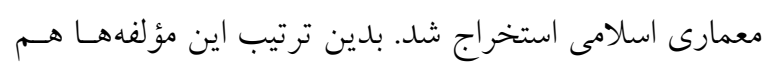




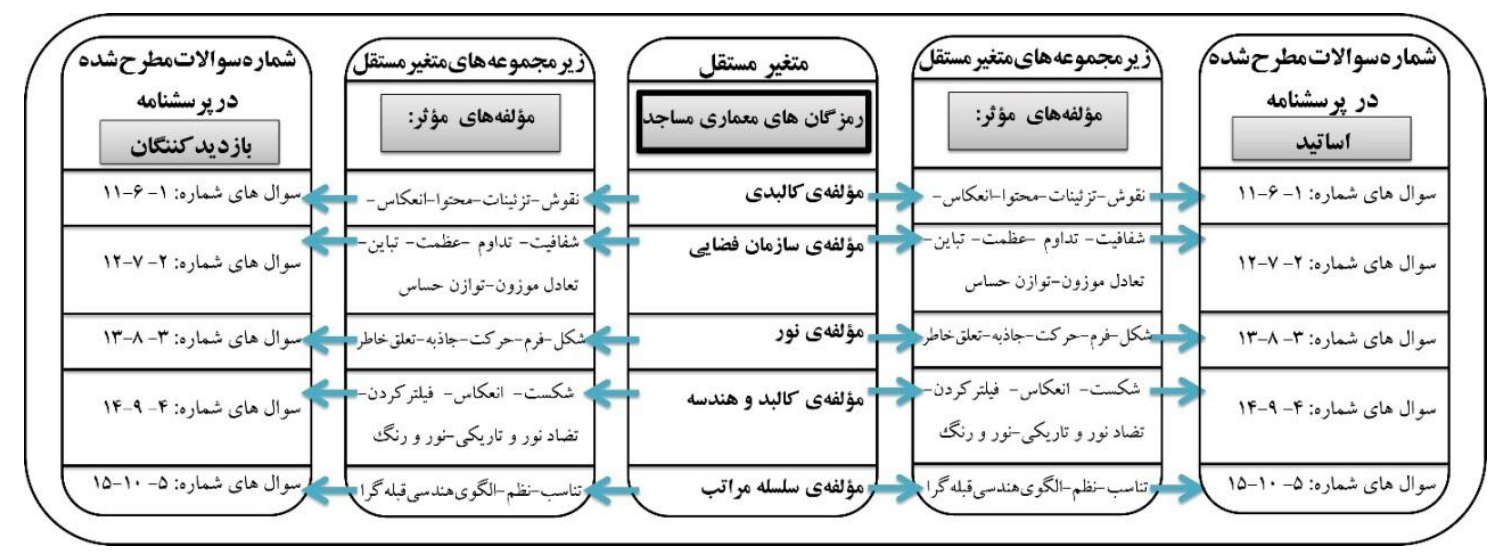

تصوير "ا: نمودار موضوعات اصلى مطرحشده در هر دو مدل يرسشنامه

Fig.3: Graph of the main issues raised in both models of the questionnaire

جدول \&: مشخصات مساجد منتخب

Table 6: Specifications of selected mosques

\begin{tabular}{|c|c|c|c|c|c|}
\hline مسجد حكيم & مسجد آقانور & مسجد شيخ لطفالله & مسجد امام خمينى (ره) & مساجد انتخابشده & رديف \\
\hline منطقه باب الدشت در انتهاى بازار & خيابان ابنسينا، محله & ضلع شرقى ميدان نقشجهان & ضلع جنوبى ميدان & موقعيت & 1 \\
\hline منطقه r & منطقه r & منطقه r & منطقه r & منطقه فعلى شهردارى & r \\
\hline 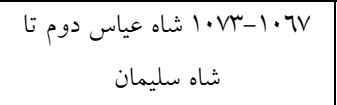 & 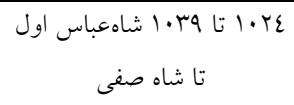 & 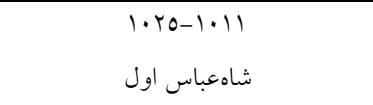 & 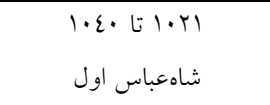 & سال تأسيس & r \\
\hline مسكونى -تجارى (هتل) & مسكونى -تجارى (هتل) & مسكونى-تجارى (هتل) & مسكونى -تجارى (هتل) & كاربرى فعلى اطر اف & $\varepsilon$ \\
\hline كاشى كارىهاى زيبا، آجركارى و & كتيبه هاى ويزئه، مهتانهاى خاصى زيبا & 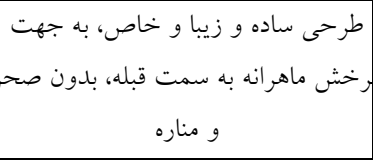 & تنها مسجد غيرمتقارن دنيا & تأكيد طرح مسجد & 0 \\
\hline حدودِ ... مثرمربع & 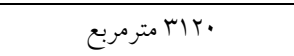 & 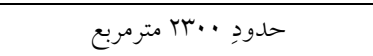 & ع ع א ا مترمربع & مساحت كل & 7 \\
\hline
\end{tabular}

جدول V: مقايسه عددى ميانگَين مؤلفهاى محاسبهشده در يرسشنامههاى اساتيد و نمازگزاران

Table 7: Numerical comparison of the mean of the calculated components in the questionnaires of professors and worshipers

\begin{tabular}{|c|c|c|c|c|c|c|c|c|}
\hline 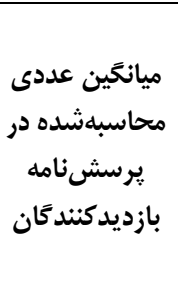 & محاسبهشده در & 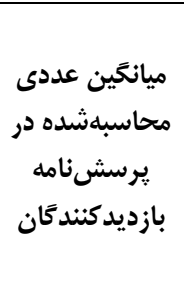 & 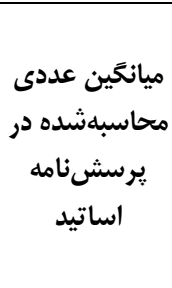 & 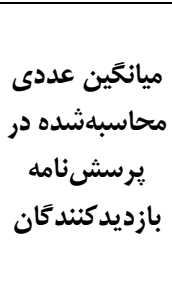 & | ميانكين & شماره سؤالات & | رمز زمان كاموموعهد & رديف \\
\hline$\varepsilon / 0 Y$ & $\varepsilon / \varepsilon V$ & $\varepsilon / 0 V$ & $\varepsilon / \varepsilon q$ & $\varepsilon / 0$. & $\varepsilon / \wedge$. & شمارههاى 1-7-11 & مؤلفه & 1 \\
\hline$\varepsilon / \varepsilon$. & $\varepsilon / \mu_{0}$ & $\varepsilon / \varepsilon 0$ & $\varepsilon / \varepsilon\rceil$ & $\varepsilon / \mu q$ & $\varepsilon / r q$ & شمارههاى Y-V-Y & سازمان & r \\
\hline$\varepsilon / \mu 1$ & $\varepsilon / \mu$ & $\varepsilon / \mu r$ & $\varepsilon / \mu r$ & $\varepsilon / T_{0}$ & $\varepsilon / \pi)$ & شمارههاى r-1-r| & نور & $r$ \\
\hline$\varepsilon / \pi$. & $\varepsilon / \tau\rceil$ & ( & $\varepsilon / \mu$ & $\varepsilon / \tau$. & $\varepsilon / \pi$. & شمارههاى ع-9-ع| & كالبدوهندسه & $\varepsilon$ \\
\hline$\varepsilon / T_{0}$ & $\{/ r)$ & $\varepsilon / \Upsilon\urcorner$ & $\varepsilon / \tau V$ & $r / 70$ & $\varepsilon / 1\}$ & شمارههاى 0-••10 & سلسلهمراتب & ० \\
\hline
\end{tabular}


بازشناسى رابطة رمز كان معمارى مساجد و كيفيت حضور قلب نماززَزاران

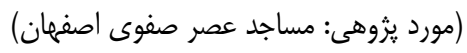

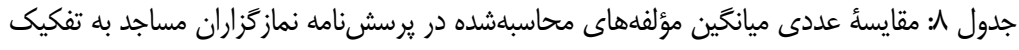

Table 8: Numerical comparison of the average of the components calculated in the questionnaire of mosque worshipers separately

\begin{tabular}{|c|c|c|c|c|c|c|c|c|c|c|c|c|c|c|c|c|}
\hline \multicolumn{3}{|c|}{ مؤ لفة سلسلهمر اتب } & \multicolumn{3}{|c|}{ مؤلفةُ كالبدوهندسه } & \multicolumn{3}{|c|}{ مؤلفهُ نور } & \multicolumn{3}{|c|}{ مؤلفهُ سازمانفضايى } & \multicolumn{3}{|c|}{ مؤلفة كالبدى } & نام مسجد بازديد شده & رديف \\
\hline سيانزده & | سؤال حه & سئج & سوارد & سؤ ال نه & سؤال & سئ سوال & سؤ س & سؤ سال & سوازد & سؤال & سؤال دو & سئ سوال & سؤ س & سئ سوال & شاره سؤالات برسشنان & \\
\hline$\varepsilon / \Gamma$ & $\varepsilon / \pi r$ & $\varepsilon / 17$ & $\varepsilon / \pi$ & $\varepsilon / \varepsilon$. & $\varepsilon / \pi T$ & $\varepsilon / \varepsilon$. & $\varepsilon / \varepsilon\rceil$ & $\varepsilon / \pi\urcorner$ & $\varepsilon / 07$ & $\varepsilon / 0 r$ & $\varepsilon / 0$. & $\varepsilon / 77$ & $\varepsilon / 77$ & $\varepsilon / \pi$ & مسجد امام خمينى (ره) & 1 \\
\hline$\varepsilon / \Gamma\urcorner$ & $\varepsilon / T \eta$ & $r / \Lambda 7$ & $\varepsilon / \pi T$ & $\varepsilon / \pi r$ & $\varepsilon / \pi r$ & $\varepsilon / r$. & $\varepsilon / \pi\urcorner$ & $\varepsilon / \pi r$ & $\varepsilon / \varepsilon r$ & $\varepsilon / 0$. & $\varepsilon / \pi \eta$ & $\varepsilon / 7$. & $\varepsilon / \pi r$ & $\varepsilon / 0$. & مسجد شيخ لطفالله & r \\
\hline$\varepsilon / \pi T$ & $\varepsilon / T \tau$ & $r / 7$. & $\varepsilon / T \tau$ & $\varepsilon / r$. & $\varepsilon / T$. & $\varepsilon / T \tau$ & $\varepsilon / \pi\urcorner$ & $\varepsilon / \pi r$ & $\varepsilon / \pi r$ & $\varepsilon / 2 r$ & $\varepsilon / \pi \eta$ & $\varepsilon / 0$. & $\varepsilon / 0 r$ & $\varepsilon / 27$ & مسجد حكيم & r \\
\hline$\varepsilon / 17$ & $\varepsilon / r$. & $r / \cdot \cdot$ & $\varepsilon / T q$ & $\varepsilon / r$. & $\varepsilon / 1 r$ & $\varepsilon / \Gamma q$ & $\varepsilon / 1 r$ & $\varepsilon / T$ & $\varepsilon / r$. & $\varepsilon / \pi 7$ & $\varepsilon / \Gamma r$ & $\varepsilon / \pi T$ & $\varepsilon / \varepsilon 7$ & $\varepsilon / \varepsilon r$ & مسجد آقانور & $\varepsilon$ \\
\hline
\end{tabular}

فضايى در ايجاد تردد عبورى بسيار اهميت دارد، زيرا سازمان فضايى و مؤلفههاى كالبدى ساختار تردد را شكل مىدهنــ و

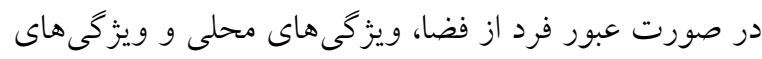

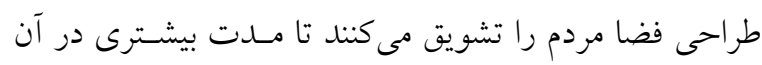

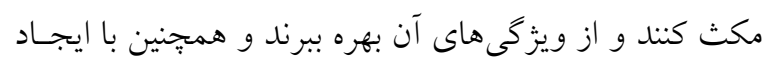
حس قداست در آنهـا بـهـ هــدف عـالى طراحسى كـه همـان نزديكى خداوند به شكل فطرى است، دست مىيابند. * در تجميع تحليل توصيفى دادههاى حاصل از دودسته يرسشنامـه (اسـاتيد و صـاحب نظــان، نمـاز گزاران مسـاجد متتخب) با توجه به نمرات كسـبـشــه ترسـيم شـد، جـدول مذكور بيانكر اين موضـوع اسـت كـه مؤلفـهـــاى كالبـدى و

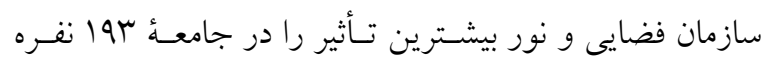

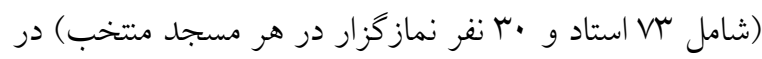

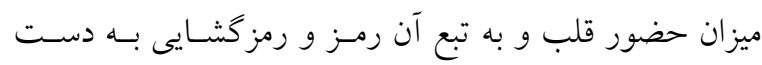

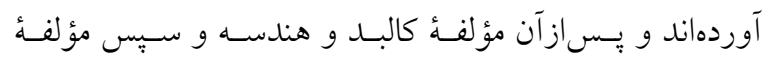
سلسلهمراتب امتياز كسب كردهاند (رجوع به جداول 9 و • (1).
مسجد و القاء حس آرامش و نزديكى به خدا دارد كه افـراد

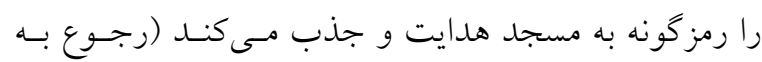

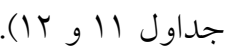
همانطور كه جداول بالا نشـان مسىهنــ، بـين عناصـر

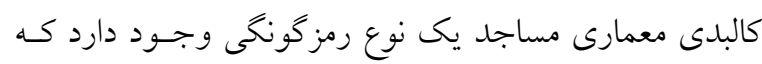

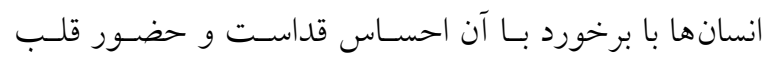
بيشترى در مساجد و بهويزٔه بخش محراب مى كنند، البته ايـن

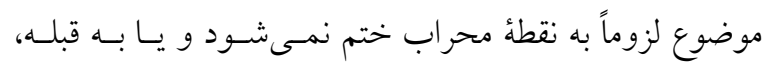

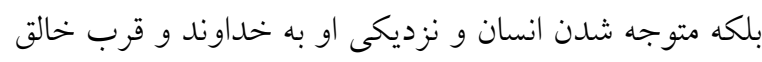
هستى، مهمترين رمز تعريفشده در مسـاجد منتخـب اسـت.

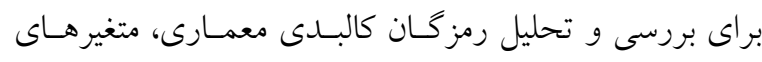

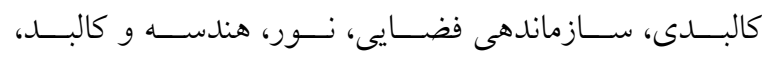

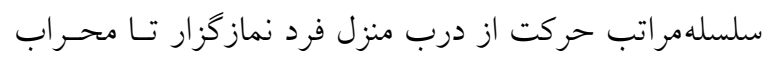

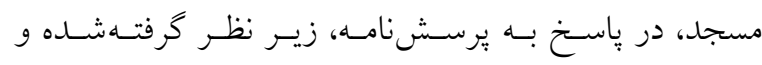
موردبررسى قرارگرفته است.

مؤلفههاى كالبدى-محتوايى معمارى مسـاجد و سـازمان

جدول ج: تحليل توصيفى دادههاى حاصل از يرسشنامه اساتيد

Table 9: Descriptive analysis of the data obtained from the professors' questionnaire

\begin{tabular}{|c|c|c|c|c|c|c|c|}
\hline $\begin{array}{l}\text { مجموع } \\
\text { Sum }\end{array}$ & ماكزيمم & Minimum & مؤلفه & $\begin{array}{c}\text { مedian } \\
\text { Median }\end{array}$ & $\begin{array}{l}\text { ميانگين } \\
\text { Average }\end{array}$ & نام مؤلفهها & 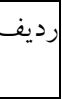 \\
\hline TrI & $7 r$ & • & . & ir & 10 & 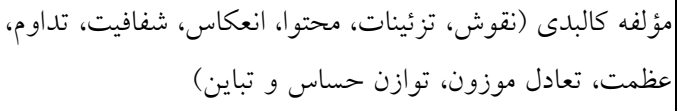 & 1 \\
\hline$r \cdot r$ & $\varepsilon r$ & · & . & 11 & 10 & مؤلفه سازمان فضايى (شكل، فرم، حركت، جاذبه و تعلق خاطر) & r \\
\hline r19 & ra & • & · & 9 & 10 & | مؤلفه نور (شكست، انعكاس، فيلتركردن، تضادنورو تاريكى و & r \\
\hline r19 & r & . & . & 9 & 10 & |مؤلفه كالبدوهندسه (تناسب، نظم، الكوى هندسى قبله گرا) & $\varepsilon$ \\
\hline r19 & rv & · & . & $\checkmark$ & 10 & |مؤلفه سلسله مراتب (اتحاد، تجمع، تركيب و ريتم) & 0 \\
\hline
\end{tabular}


جدول • •ا: تحليل توصيفى دادهاى حاصل از برسشنامه نمازگزاران

Table 10: Descriptive analysis of the data obtained from the worshipers' questionnaire

\begin{tabular}{|c|c|c|c|c|c|c|c|}
\hline مجموع & ماكزيمم & مينيمتم & مؤلفه & ميانه & ميانخين & نام مؤلفهها & رديف \\
\hline r)l & VV & - & - & $r$. & $r \varepsilon$ & مؤلفه كالبدى (نقوش، تزئينات، محتو ا، انعكاس، شفافيت، عظم، تعادل موزون، توازن حساس و تباين) & 1 \\
\hline r) & 70 & • & • & 11 & $T \varepsilon$ & مؤلفه سازمان فضايى (شكل، فرم، حركت، جاذبه و & r \\
\hline r. & 07 & · & • & 17 & $r \varepsilon$ & و مؤلفه نور (شكست، انعكاس، فيلتركردن، تضادنورو تاريكى & r \\
\hline r. & $0 \wedge$ & • & · & 1. & rE & مؤلفه كالبدوهندسه (تناسب، نظم و الخوى هندسى قبله گر|) & $\varepsilon$ \\
\hline ro. & 7. & · & · & 1. & $r \varepsilon$ & مؤلفه سلسلهمراتب (اتحاد، تجمع، تركيب و ريتم) & 0 \\
\hline
\end{tabular}

جدول (l: شيوهُ تفسير شدت رابطه در روش تحليل واريانس خند متغيره (Miller 2001)

Table 11: The method of interpreting the intensity of the relationship in the method of multivariate analysis of variance (Miller 2001)

\begin{tabular}{|c|c|}
\hline تفسير & شدّت رابطه \\
\hline رابطه بسيار قوى & 1/. تا I 1 \\
\hline رابطه قوى & آح/. تا م/. \\
\hline رابطه متوسط & عـ/ عا ר/. \\
\hline رابطه كم (ضعيف) & r / تا ع/. \\
\hline فقدان رابطه يا رابطه ناجيز & صفرتا ب/. \\
\hline
\end{tabular}

مؤلفهُ سازمان فضايى با وزن نسبى 7r// • و سبس مؤلفهُ نـور

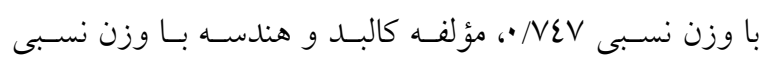

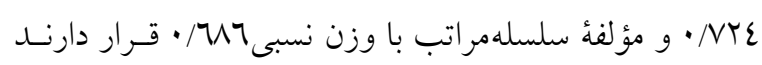

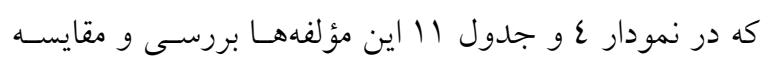

شدهاند (رجوع به نمودار ع و جدول (1)).
شتنتايج يزووهش آزمون MANOVA نشان داد كه با بررسى

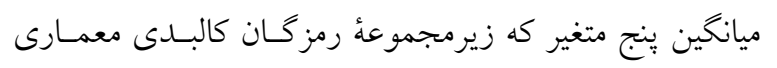

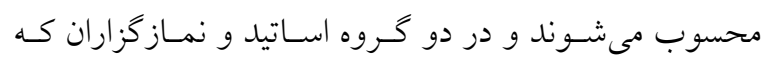

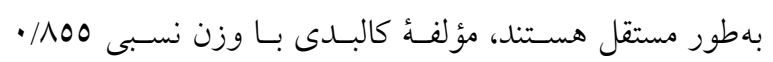

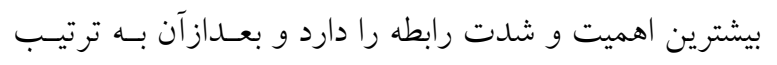

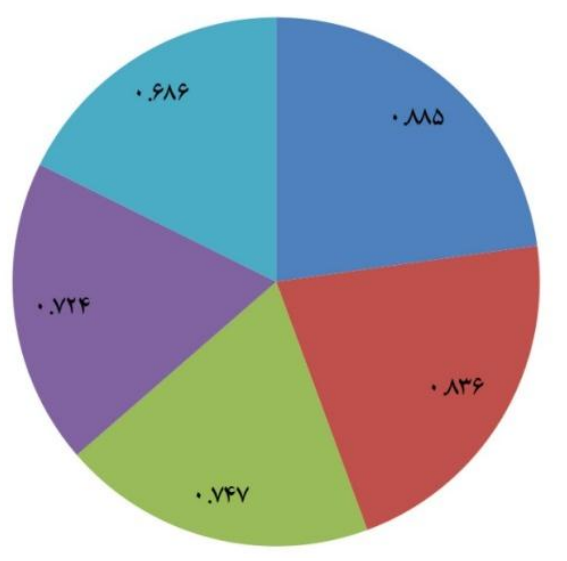

$$
\begin{aligned}
& \text { | مؤلفه كالبدى(نقوش-تزئينات-محتوا-انعكاس } \\
& \text { شفافيت-تداوم-عظمت-تعادل-توازن-تباين) }
\end{aligned}
$$

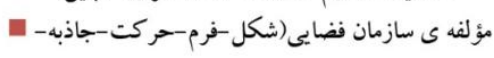

$$
\begin{aligned}
& \text { تعلق خاطر) }
\end{aligned}
$$

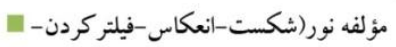

$$
\begin{aligned}
& \text { تضادنورور تاريكى -نورورنگگ }
\end{aligned}
$$

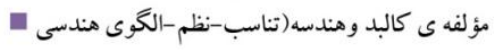

$$
\begin{aligned}
& \text { قبله كرام } \\
& \text { |مؤلفه سلسله مراتب(اتحاد-تجمع -تركيب-ريتم) }
\end{aligned}
$$

تصوير أ: مؤلفهاى موردبررسى قرارگرفته

Fig. 4: Components examined

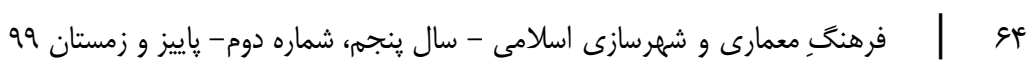


بازشناسى رابطة رمز كان معمارى مساجد و كيفيت حضور قلب نماززَزاران

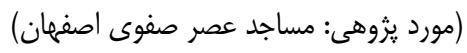

جدول rا: خروجى تحليل دادههاى آزمون فريدمن

Table 12: Friedman test data analysis output

\begin{tabular}{|c|c|c|c|}
\hline \multicolumn{4}{|c|}{ Test Statisticsa } \\
\hline \multicolumn{2}{|r|}{ تعداد اساتيد } & $\mathrm{N} 1$ & 73 \\
\hline \multicolumn{2}{|c|}{ ت تعداد بازديدكند كان } & N2 & 120 \\
\hline 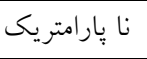 & آزمون تطابق توزيع مربع كاى & Chi-Square & $163.74 \mathrm{a}$ \\
\hline \multicolumn{2}{|c|}{ درجه آزادى اساتيد } & Df professor & 4 \\
\hline \multicolumn{2}{|c|}{ مرجه آزادى بازديدكنندكان } & Df visitors & 4 \\
\hline \multicolumn{3}{|c|}{$\begin{array}{ll}\text { Asymp. Sig. } \\
\end{array}$} & .000 \\
\hline \multicolumn{4}{|c|}{ a. Friedman Test } \\
\hline
\end{tabular}

جدول سا: خروجى تحليل دادههاى آزمون فريدمن

Table 13: Friedman test data analysis output

\begin{tabular}{|c|c|c|c|c|c|c|}
\hline Mean Rank & $\begin{array}{c}\text { Mean } \\
\text { visitors }\end{array}$ & $\begin{array}{c}\text { Mean } \\
\text { professor }\end{array}$ & N2 & N1 & 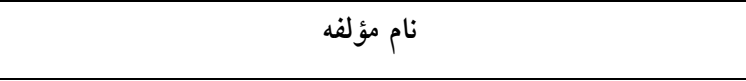 & رديف \\
\hline V/Vq & $V / T V$ & $V / 91$ & Ir. & $v r$ & 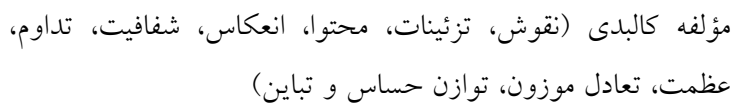 & 1 \\
\hline $0 / .0$ & $0 / Y_{1}$ & $\varepsilon / \wedge 9$ & ir. & $v r$ & مؤلفه سازمان فضايى (شكل، فرم، حركت، جاذبه، تعلق خاطر) & r \\
\hline$\varepsilon / 99$ & $0 / 14$ & $\varepsilon / 10$ & Ir. & $v r$ & رؤَلفه نور (شكست، انعكاس، فيلتركردن، تضاد نور و تاريكى، نور و & $r$ \\
\hline$\varepsilon / \varepsilon \wedge$ & $\varepsilon / V \wedge$ & $\varepsilon / \wedge$ & $i r$. & $v r$ & مؤلفه كالبد و هندسه (تناسب، نظم، الخوى هندسى قبله كرا) & $\varepsilon$ \\
\hline$r / \mu$ & $r / \mu \varepsilon$ & $r / \Upsilon \Lambda$ & $M \cdot$ & $v r$ & مؤلفه سلسلهمراتب (اتحاد، تجمع، تركيب، ريتم) & 0 \\
\hline
\end{tabular}

معمارى اسلامى و مخاطبـان خـاص (معمـاران)، بـه ترتيـب

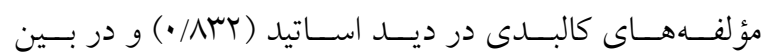
نمازگزاران (AVN/ •) و مؤلفه سازمان فضـايى از ديـــ اسـاتيد

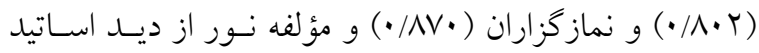

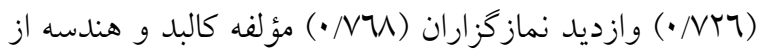

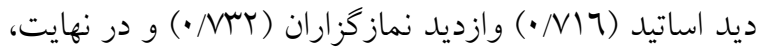

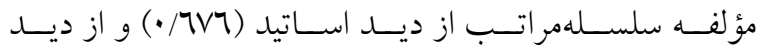
نمازگزاران (797/•) بوده و مؤلفه كالبــى بـا ميـزان ضـريب همبستخى (100/•) در بين دو دسته برسـش شـوندههـا رتبـهـ

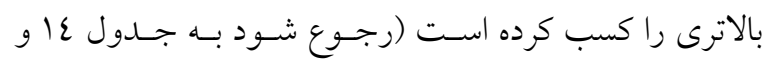

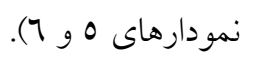
در تحقيق حاضر، تأثير رمزگان كالبدى معمارى مسـاجد بر ميزان حضور قلـب در نمـاز گزاران جهـت تحقـق حضـور حداكثرى در ساختار كالبـدى مسـاجد دورة صـفوى بررسىى مئى

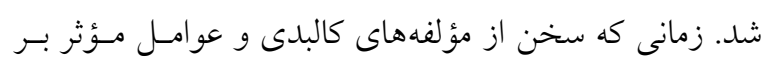

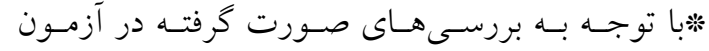
فريدمن اين نتيجه به دست مى آيد كه رابطة بين مؤلفههـا اولاً معنادار است و ميزان خطا با توجه بـهـ بررسـى انجـامشــه و فرضية صفر ه رد شد؛ و اندازهُ مقدار مركزى ارزش مؤلفهها يـاـ

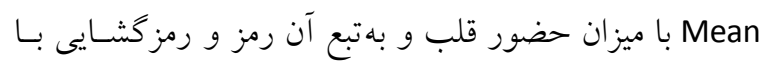

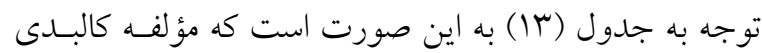
بالاترين تأثير (V/V9) و مؤلفه سلسلهمراتـب (اس/M) كمتــرين

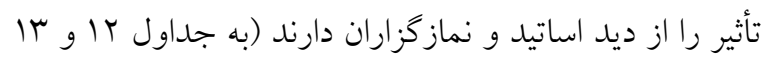
رجوع كنيد).

جقبا استفاده از آزمون اسسيرمن Spearman's rho و ميانـه

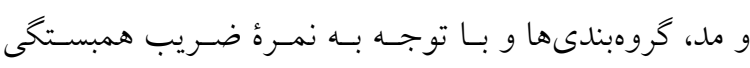

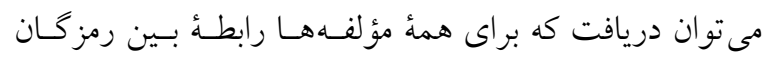

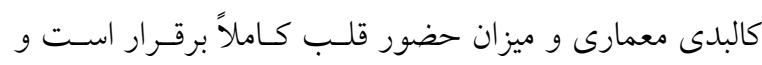

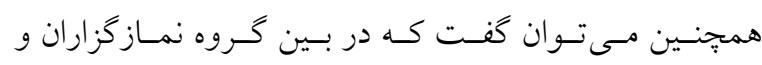

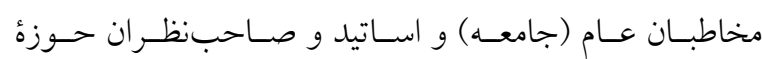


جدول عا تحليل دادهها با استفاده از آزمون اسبرمن حاصل از هر دودسته يرسشنامه

Table 14: Data analysis using Spearman test obtained from both categories of questionnaires

\begin{tabular}{|c|c|c|c|c|c|c|c|c|c|c|}
\hline \multirow{2}{*}{ ضرايب } & \multicolumn{4}{|c|}{ Spearman's rho } & \multirow[b]{2}{*}{$\begin{array}{c}\text { ميانه } \\
\text { Median } \\
\text { دگانديدكن: }\end{array}$} & \multirow[b]{2}{*}{$\begin{array}{c}\text { ميانه } \\
\text { Median } \\
\text { اساتيد }\end{array}$} & \multirow[b]{2}{*}{\begin{tabular}{|c} 
مؤلفه \\
Mode \\
كانديد كنند \\
بان
\end{tabular}} & \multirow[b]{2}{*}{$\begin{array}{c}\text { مؤلفه } \\
\text { Mod } \\
\text { e }\end{array}$} & \multirow[b]{2}{*}{ نام مؤلفهها } & \\
\hline & 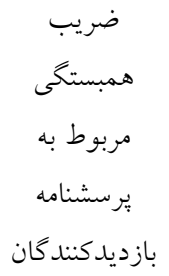 & هربت هربستى & $\begin{array}{c}\text { بازديد كنند } \\
\text { N2 } \\
\text { N2 }\end{array}$ & $\begin{array}{l}\text { تعداد } \\
\text { N1 }\end{array}$ & & & & & & \\
\hline$\cdot / 1 \wedge 0$ & $\cdot / \Lambda \vee \Lambda$ & • & Ir. & Vr & $r$. & IT & . & - & مؤلفه كالبدى & 1 \\
\hline •/ArT & $\cdot / \wedge \vee \cdot$ & $\cdot / \Lambda \cdot r$ & $\pi$. & $v r$ & 11 & 11 & • & - & مؤلفه سازمان فضايى & r \\
\hline$\cdot / V \varepsilon V$ & $\cdot / \mathrm{V} T \Lambda$ & • NYT & Ir. & V & 17 & 9 & - & - & مؤلفه نور & $r$ \\
\hline$\cdot / N Y \varepsilon$ & $\cdot$ / NTr & $\cdot / 217$ & $1 T$. & Vr & 1. & 9 & . & . & مؤلفه كالبدوهندسه & $\varepsilon$ \\
\hline$\cdot / \backslash \wedge \top$ & $\cdot / 797$ & $\cdot / 7 \vee 7$ & Ir. & VT & 1. & V & . & . & مؤلفه سلسله مراتب & 0 \\
\hline
\end{tabular}

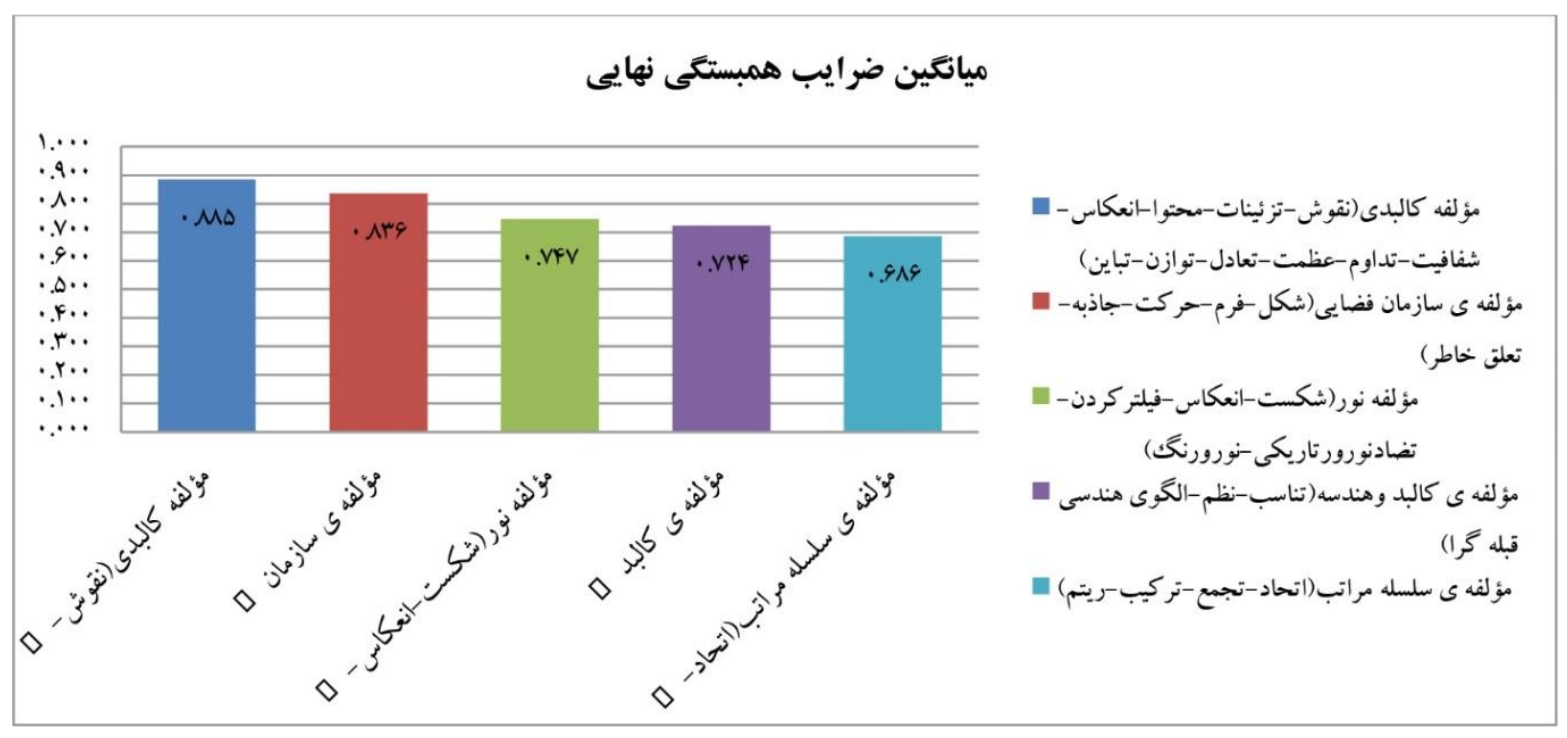

تصوير ه: مقايسه يارامترهاى مؤثر بر ميزان حضور قلب و رمزگشايى در مساجد

Fig. 5: Comparison of parameters affecting the presence of heart and decoding in mosques

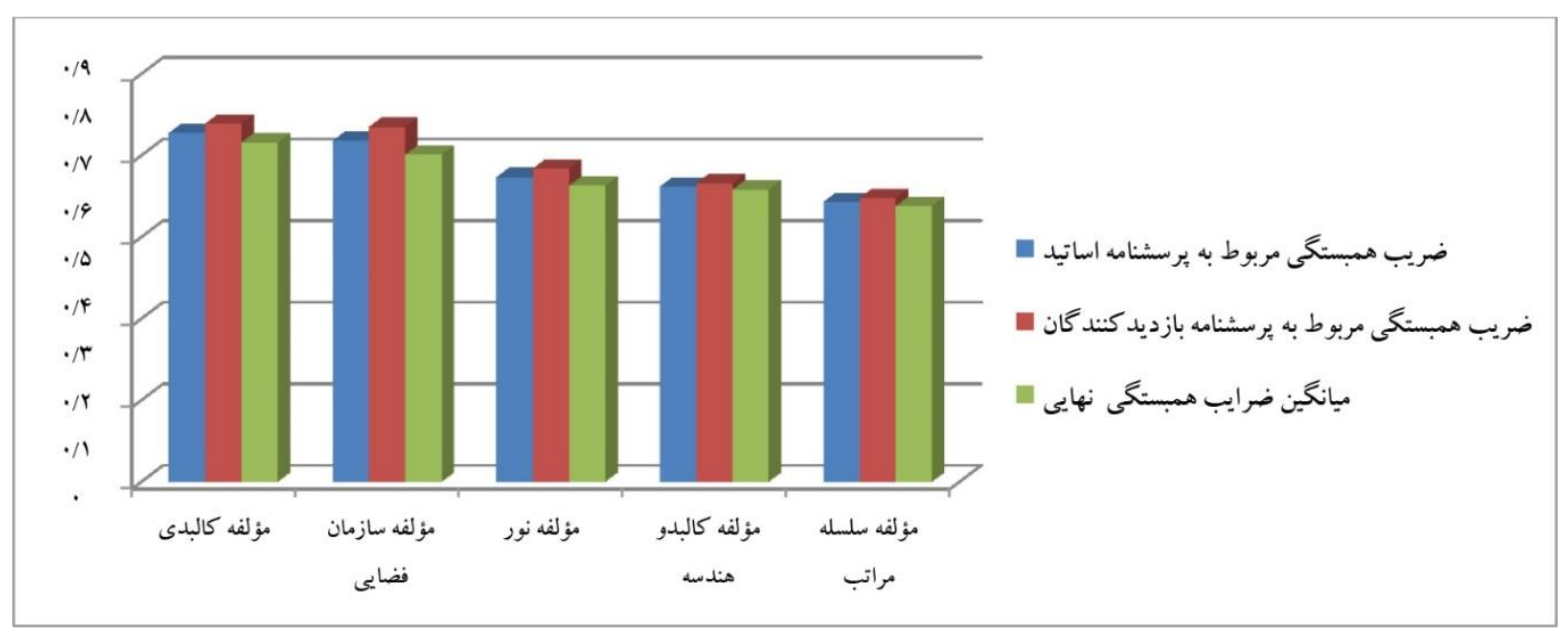

تصوير ك: ضرايب همبستخى بر اساس آزمون اسبرمن ازنظر دو گروه اساتيد و نمازگزاران

Fig. 6: Correlation coefficients based on Spearman test in terms of two groups of teachers and worshipers

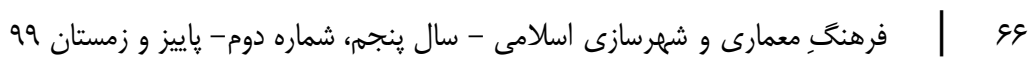


بازشناسى رابطة رمز كان معمارى مساجد و كيفيت حضور قلب نماززَزاران

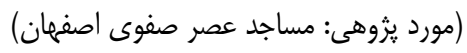

معمار و طراح مسجد محقق مسىـود. اصسلىتـرين حقيقـت

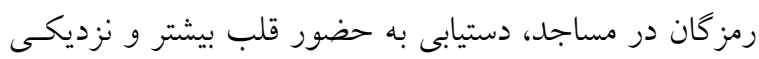

به خداوند است. (Ahmadi et al.2020).

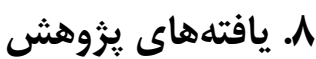

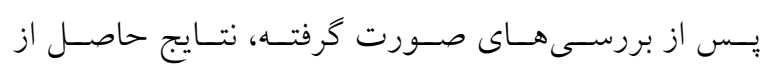

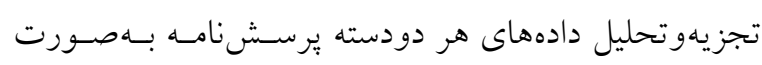
جزئى و كاربردى زير حاصل شد:

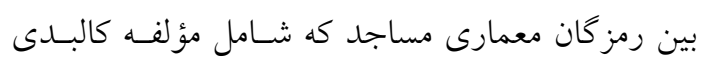

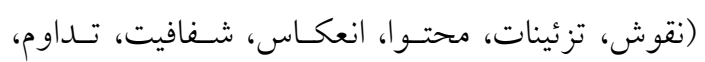

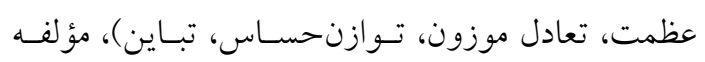

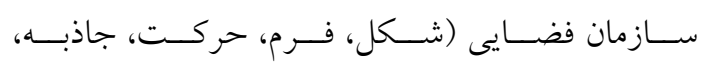

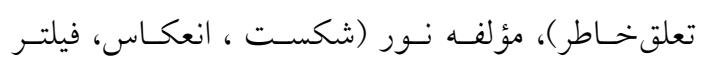

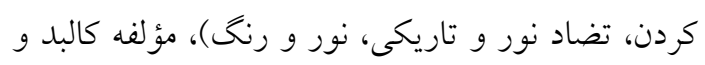

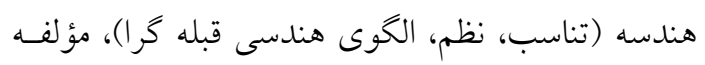

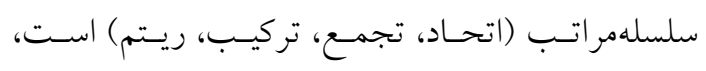
همبستخى وجود دارد.

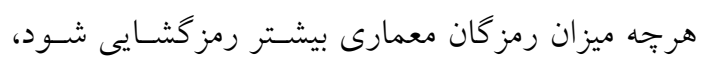

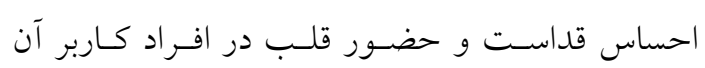
مسجد بيشتر مى احود.

رمزهايى كـه در مسـاجد دورهٔ صـفوى توسط معمدار

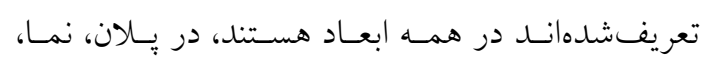
تزئينات، هندسه (كالبد)، اعداد، خطوط، حتسى عناصـر طبيعى :جون درختان، آب در حوض حياط مسجد و...؛

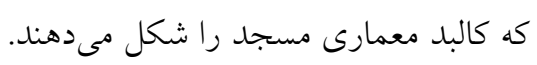

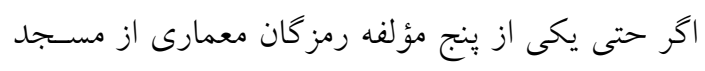

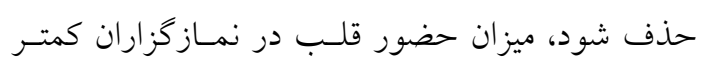
مىشود.

هماهنگى و به كاركيرى بنج مؤلفهُ زيرمجموعه رمزگحان

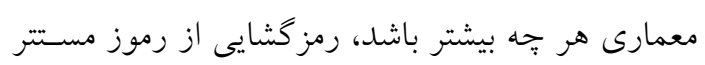

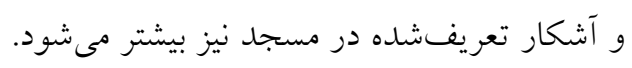

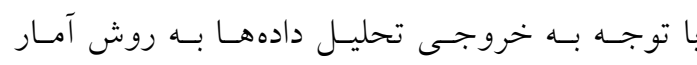

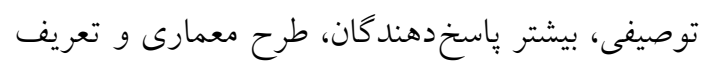
جخونكى طراحى و قرارگيرى عناصر مانند كنبد، مناره،
ميزان حضور قلـب مطـرح مسى شـود، جـاى سـخن بسـيارى

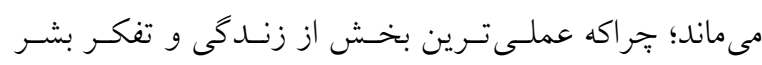
حقيقت اصلى و رمز بزرى بناى مسجد يعنى (اتفكر و انديشه

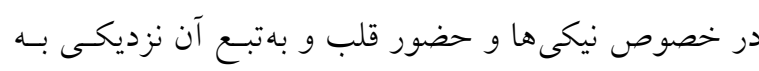

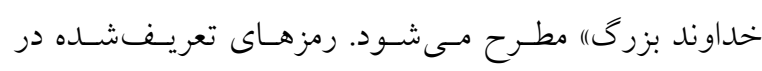

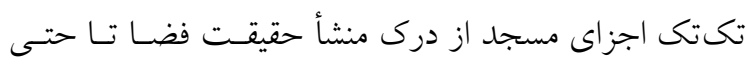
كاشى كارىها و در حقيقت ايجاد ارتباط بين زمين و آسـمان،

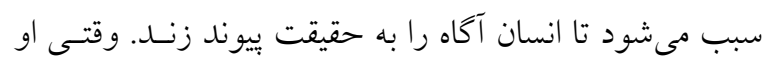

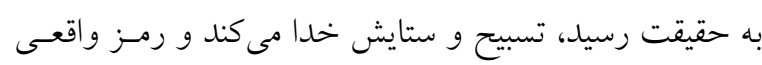

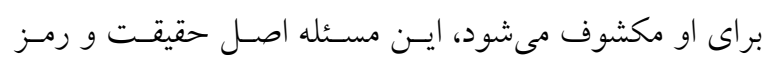

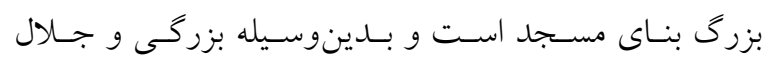

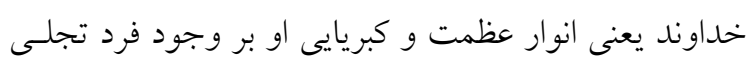

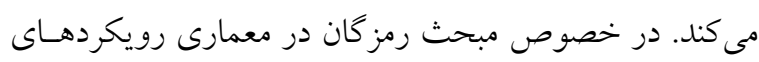

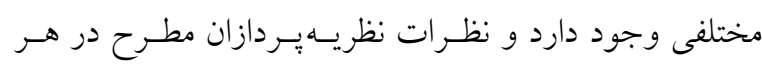

$$
\text { رويكرد در ادامه بيان مىشود. }
$$

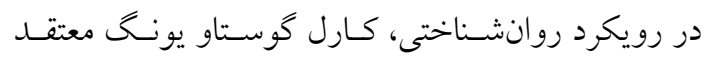
است نماد جيزى مهم است كه بـهوواسطة ادراك افـراد، قابـل

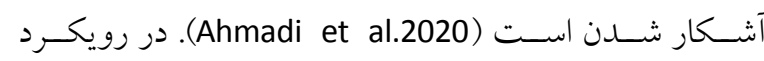
زبانشناختى، فرديناند دوسوسور معتقد است موفقيت طراح و

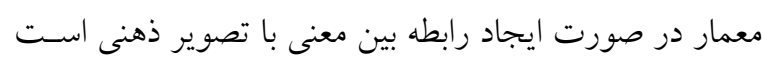

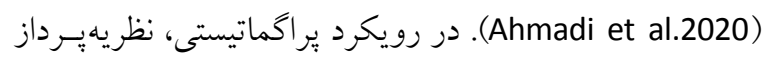
مطرح اين رويكرد يِرس است كه معتقد است، ايجاد حضـور قلب به عالى ترين شكل آن در مساجد، با كشف رابطـهُ رمـوز

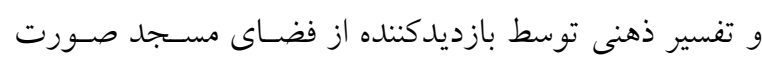

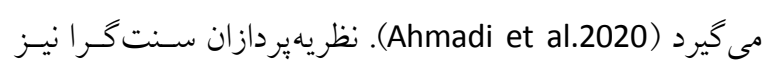

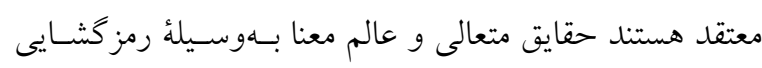

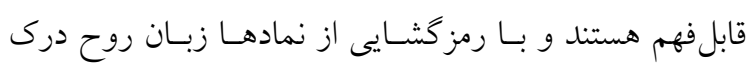

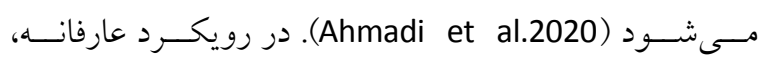

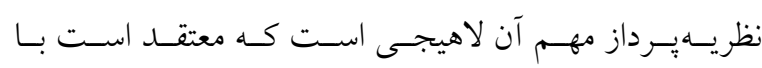

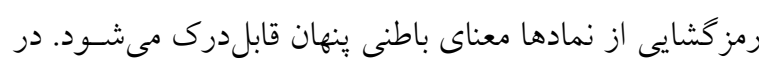

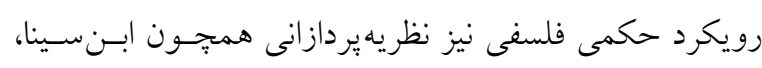

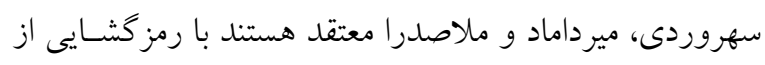

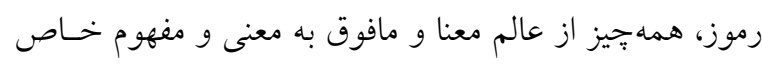

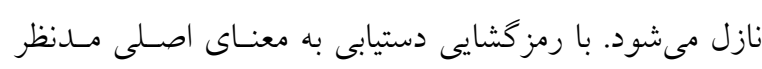


براى طر احى مسجد ماندكار و غنى به لحاظ معمارى و

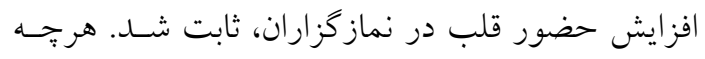

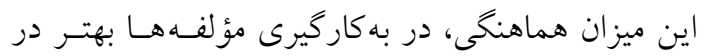

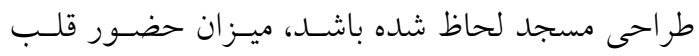
نماز كزاران در آن مسجد بيشتر مىشوده.

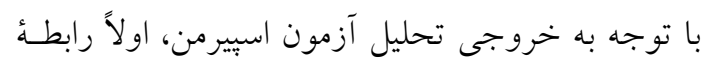

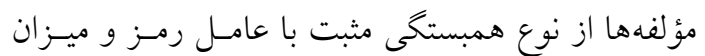

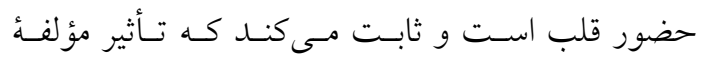

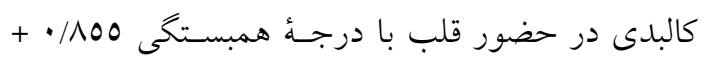

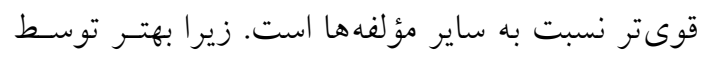
مخاطبان عام جامعه درك، تحليل و معنى مسى شــود و تأثير بيشترى بر آنان مى گذاردان

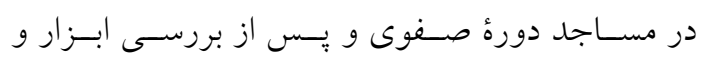

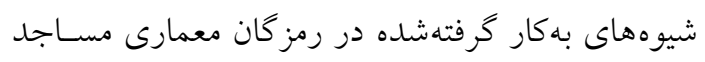

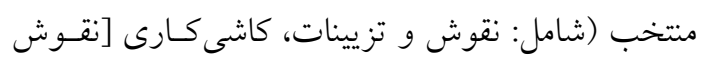

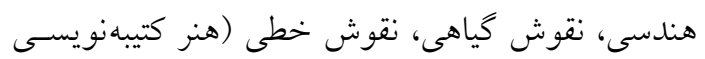

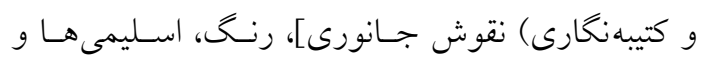
ختايىها، مقرنسها، اعـداد، نـور در معمـارى مسـاجد

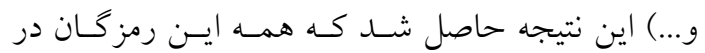

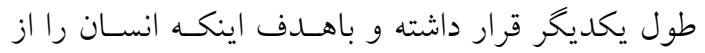

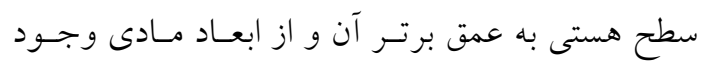
انسان به ابعاد عقلى و روحسى او برسـانند، طراحسى و

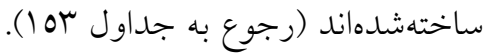

شبستان و محراب را مهم بيان كـردهانـا، همجنـين بـهـ

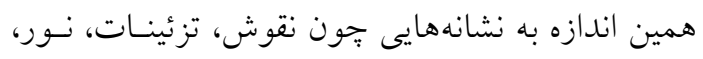
تناسبات، نظم، ريتم و اتحاد؛ حتى اذان و صوت اشـاره

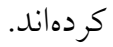
• مؤلفههاى كالبدى -محتوايى معمارى مساجد و سـازمان

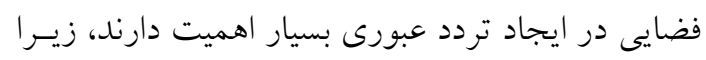
سازمان فضايى و مؤلفههـاى كالبـدى سـاختار تـردد را شـكل مسىدهنــد و در صـورت عبـور فــرد از فضـا،

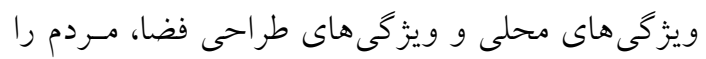

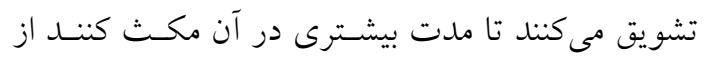

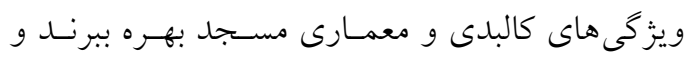

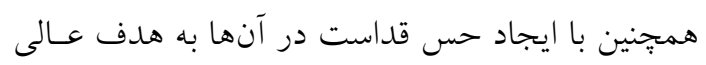

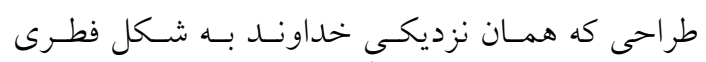

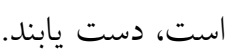

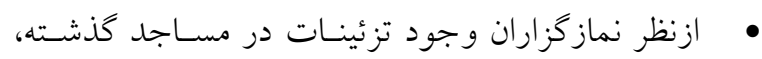
همينطور به لحاظ كالبدى، بزركى مساجد كه عظمـت

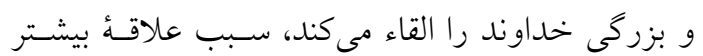
آنان جهت حضور بيشتر در آن مسجد مىشى خدوند.

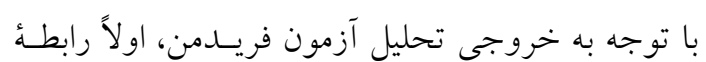

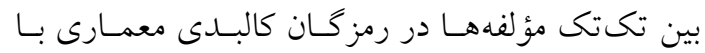

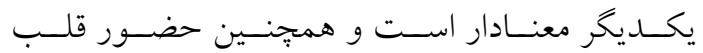

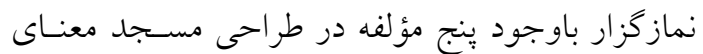

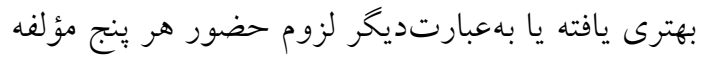

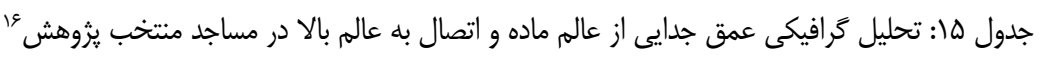

Table 15: Graphic analysis of the depth of separation from the material world and connection to the upper world in selected mosques of research

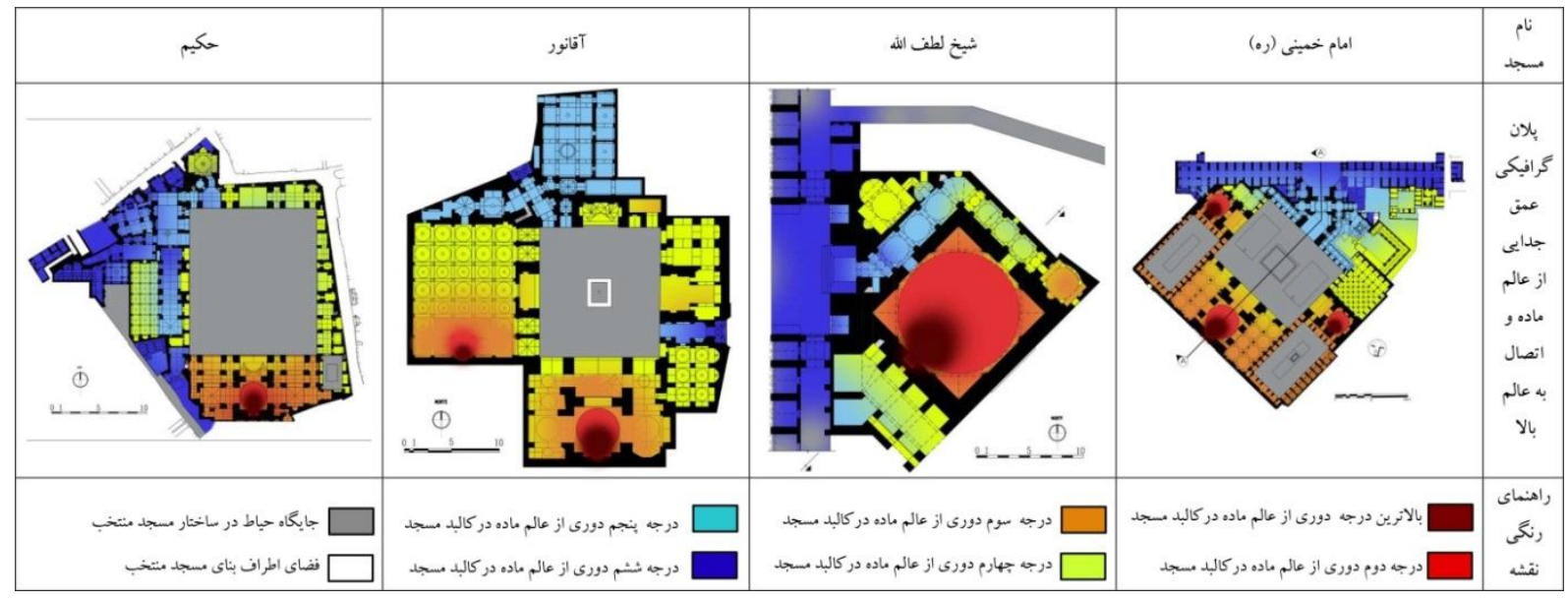

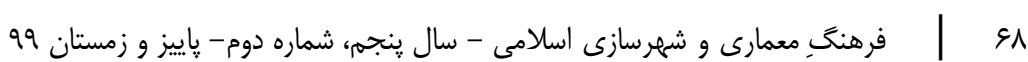


بازشناسى رابطة رمز كان معمارى مساجد و كيفيت حضور قلب نماز زَزاران

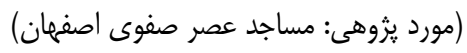

\section{نتيجه كيرى}

انسانى هست تا با شناخت كام بردارد؛ بدون شناخت هم مسى

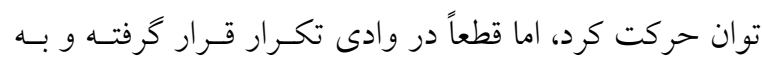

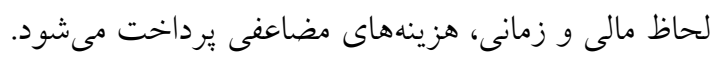

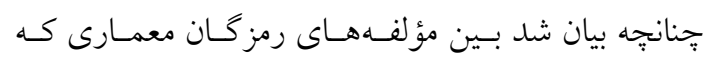

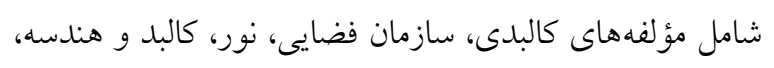

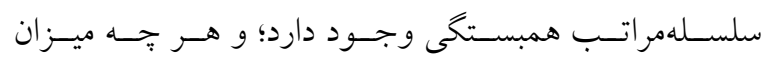

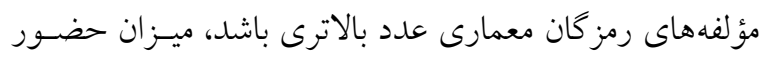

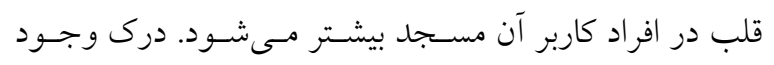

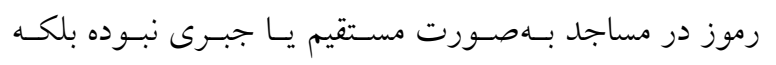

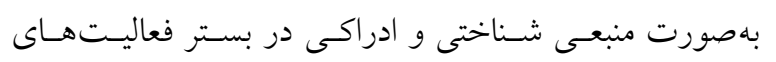

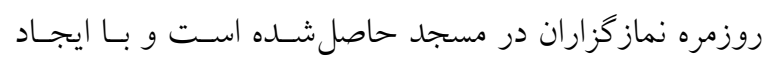

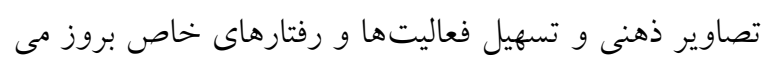

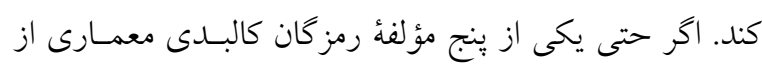

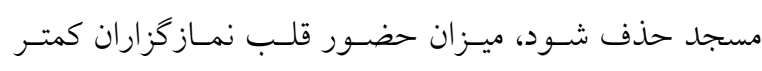

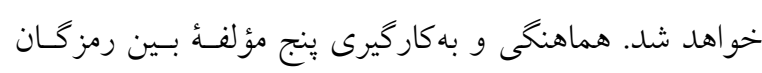

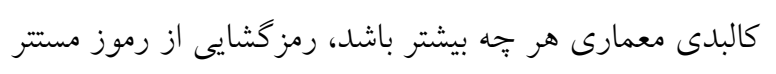

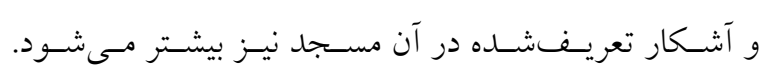
نماز گزارانى كه ارتباط مداومترى با مساجد دارند، بـه عناصـر

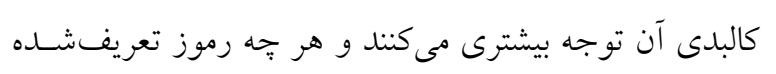

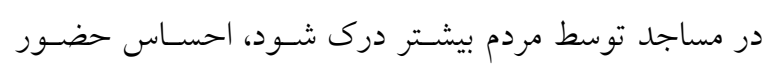

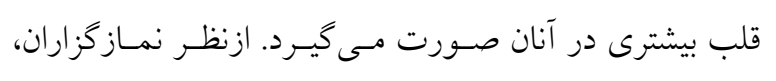

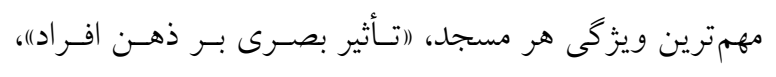

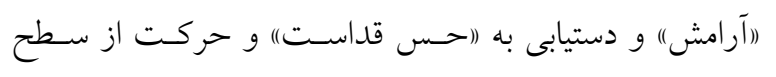

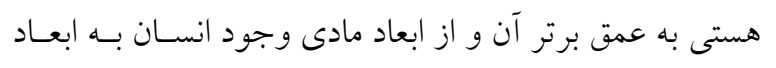
عقلى و روحى او است.

با بررسى هاى صورت كرفته در مساجد متتخب شهر اصفهان

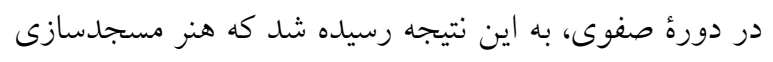
در اين دوره به سمت الكويى انتزاعى حركت مى كنـــ اسـلام

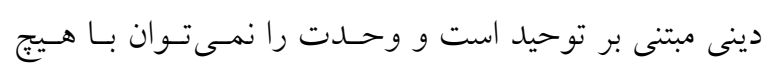

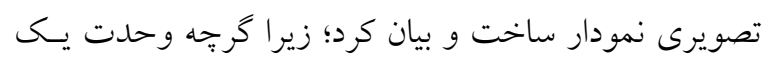

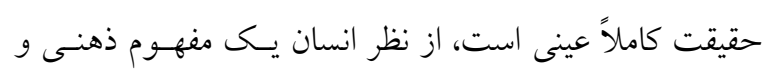
انتزاعى محسوب مىشود. تمام عناصر هنر اسلامى اشـاره بـهـ

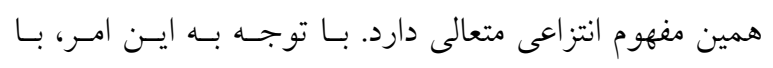
نخرشى خاص به الكوى مساجد در دورة صفوى يرداخته شد.

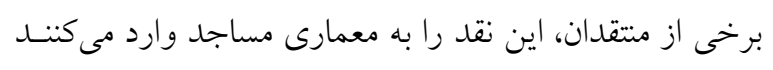

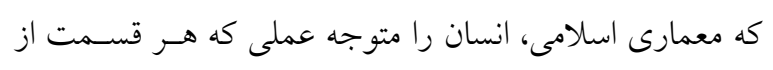

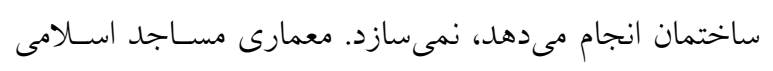

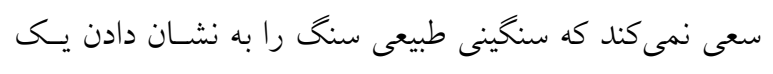

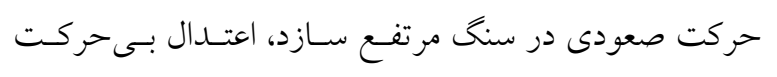

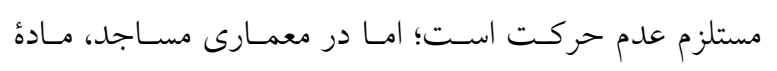

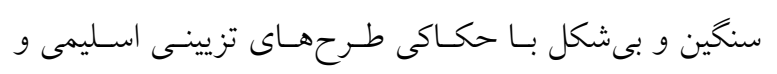
حجارى به اشكال مقرنس و مشبك، سـبكى شَبيه بـه اشـياء

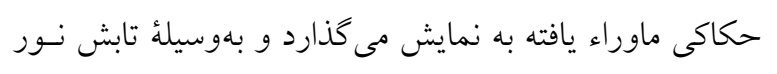
بر هزار جهت، سنگ و گج را بدل به جوهرى قيمتى مى سازد.

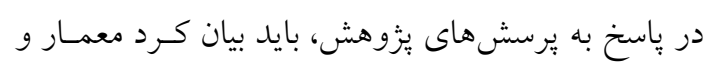

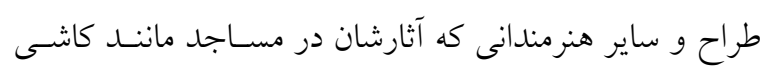
كارى، خطاطى، كتيبهنويسى و...وجود دارد، انسان نماز خزار را

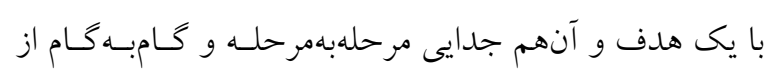

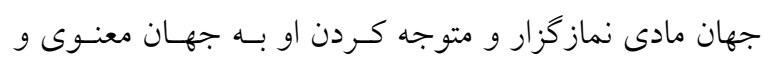
درنهايت خداوند متعال و عظمت و بزركى آن وجـود مطلـق،

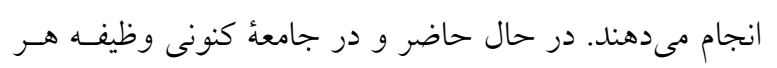

\section{سياسگَزارى}

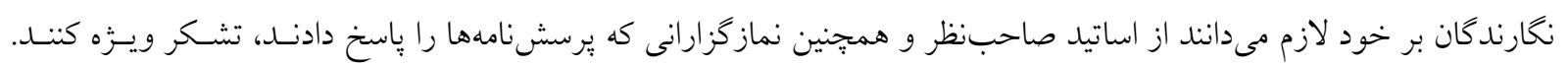

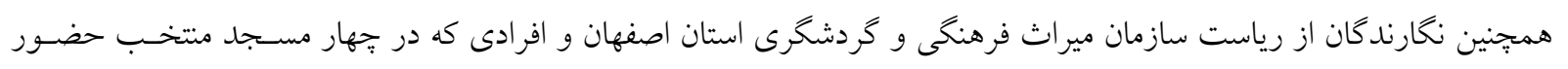


داشتند و اجازه فيلمبردارى و عكاسى را دادند، نهايت سياس را دارند و به دليل اينكه مقالـه از رسـاله دوره دكتـراى تخصصسى بـا عنوان ((تحليل مؤلفه هاى رمزگشايى معمارى سنتى ايران (نمونه موردى مساجد صفوى اصفهان))، استخراجشـده، مراتـب تقـدير و تشكر صميمانه را از كاركنان دانشخاه آزاد اسلامى واحد مشهل، بهويزه معاونت محترم بزووهش دانشخاه اعلام مى دارند.

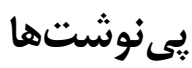

ا- در اصطلاح نشانه شناسى رمز حان عبارت است از وضعيتى خاص در سير تاريخى مجموعه نمايه ها يـا نشـانه هـا كـهـ بـهـ منظـور تحليـل همزمان مشخص شده است (Zeymaran 2014, 85).

2- Rudolf Arnheim

3-Carl Gustove Yung

4-Anne Tinger

5-Clare Cooper

6-Gibson

7-Jon Lang

8-Jose Naser

9- درآمار و احتمالات، براى بررسى يك فرضيه، درآغاز فرض تهى را يذيرفته شده تا با رد آن فرضيه اصلى اثبات شود.

(Probability and Statistics in Engineering And Management Science, William W.Hines, Douglas C.Montgomery,Third Edition,John Wiley and Sons,1990, ISBN 0-471-60090-30)

كاربرد فرض تهى در علوم آزمايشى براى هم سنجى نمونه ى آزمايش شده با نمونهُ كنترل است. به بيان ديخــ درآغـاز فـرض مسىشـود كـه

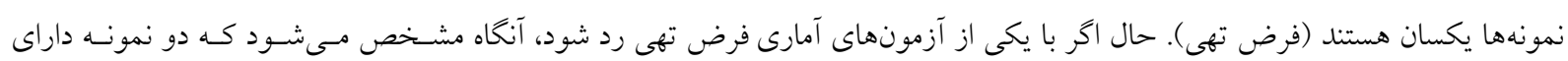

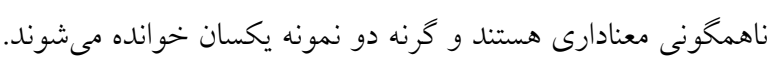

\section{فهرست منابع}

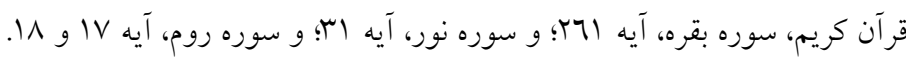

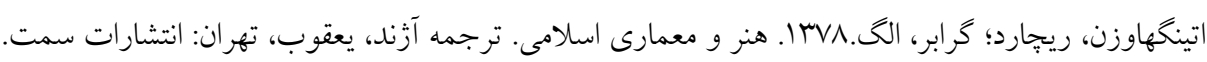

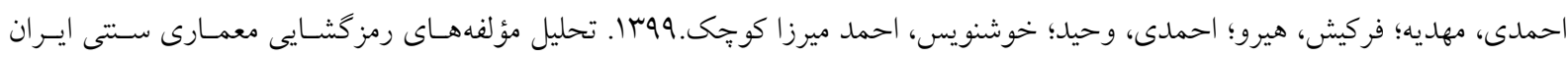

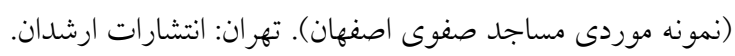

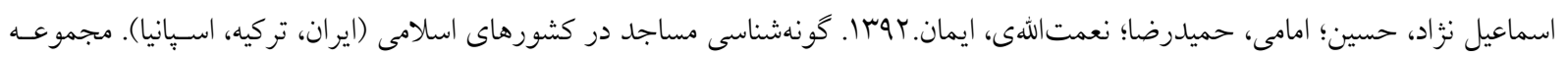
مقالات اولين همايش ملى جغرافيا، شهرسازى و توسعه بايدار، تهران: انجمن محيطزيست كومش و و دانشكاه صنعت هوايى، فروردين.

اعوانى، غلامرضا.00با. حكمت و هنر معنوى. تهران: كروى.

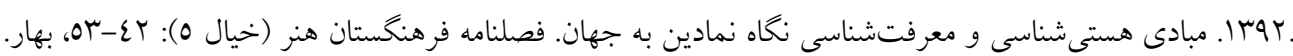

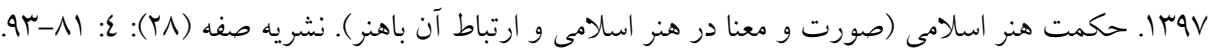

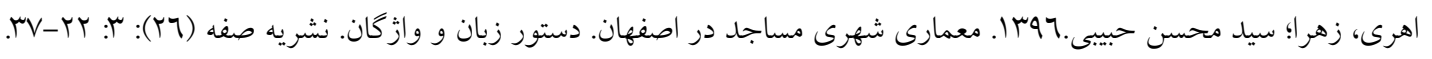

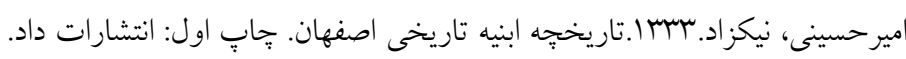
بين فيشر، ويليام.07 إ. تاريخ ايران كمبريج (·r جلدى). ترجمه قادرى، تيمور، تهران: انتشارات مهتاب.

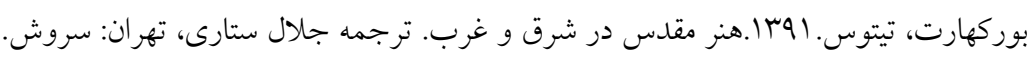

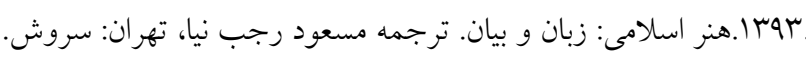

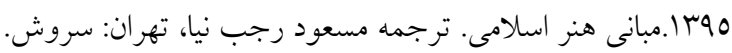

$$
\begin{aligned}
& \text { يارسانيا، حميد.بهوا. نماد و اسطوره. قم: مركز نشر اسراء. }
\end{aligned}
$$

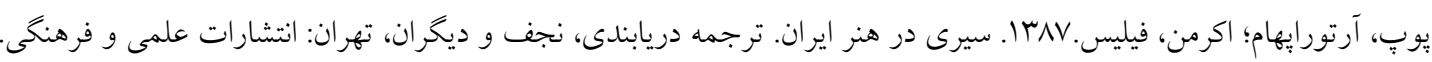

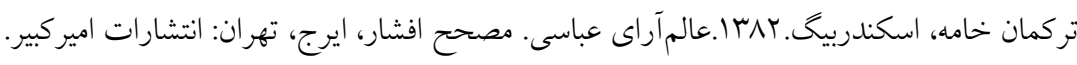

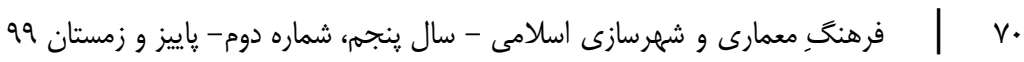




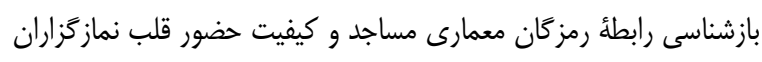

(مورد يزوهى: مساجد عصر صفوى اصفهان)

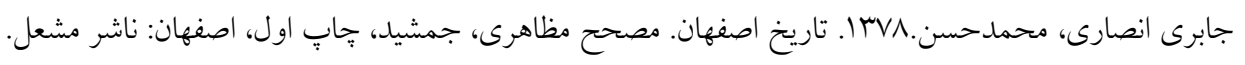

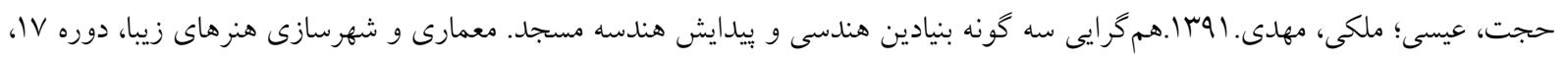
ش ع: $17-0$.

ربن شه، ليلا؛ سلطانزاده، حسين؛ قديرى، بهرام.

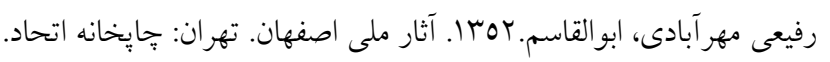

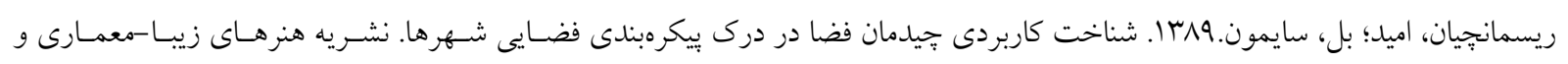

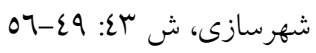

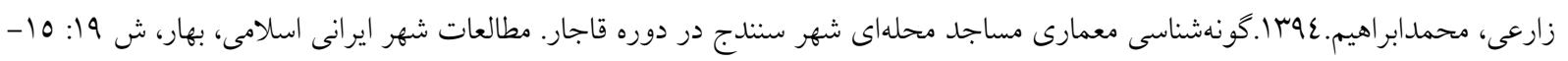

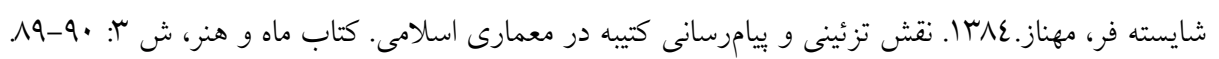

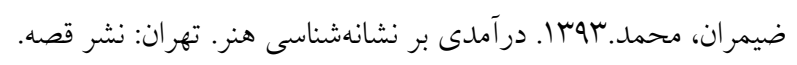

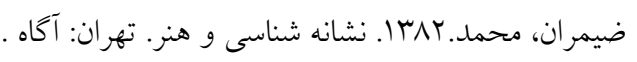

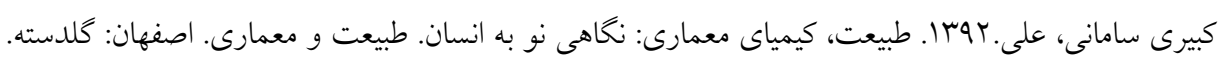

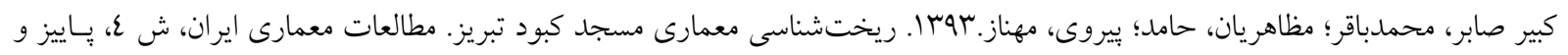

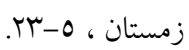

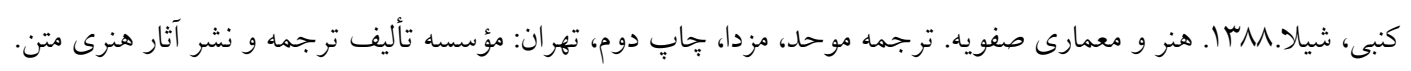

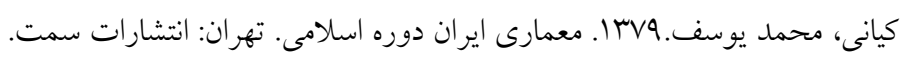

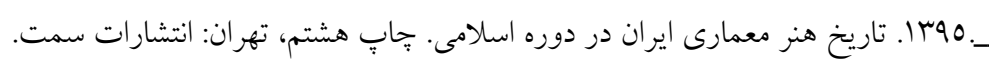

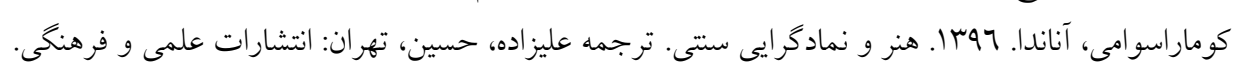

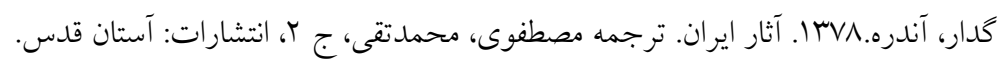

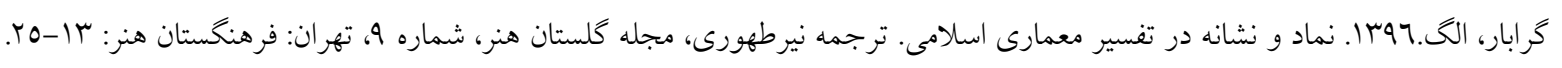

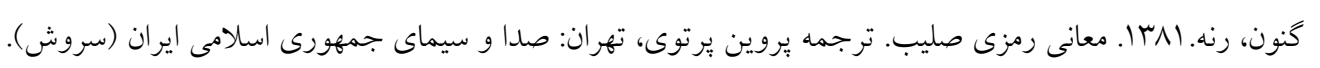

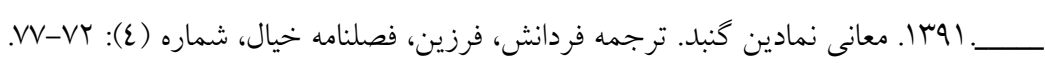

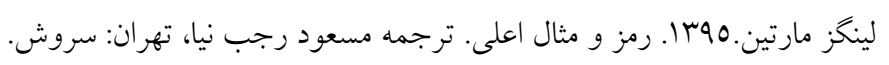

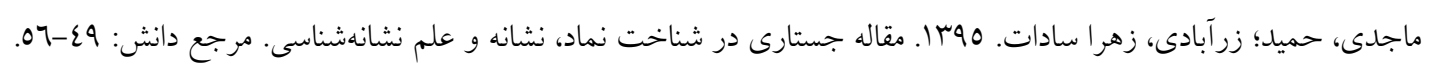

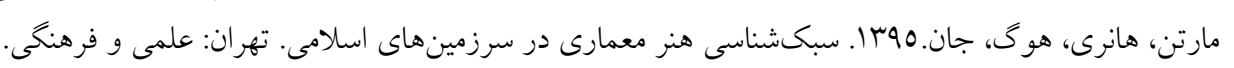

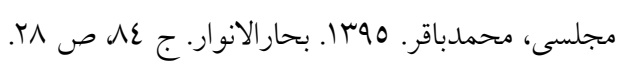

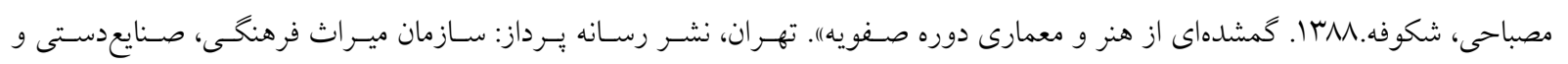

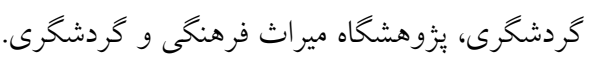

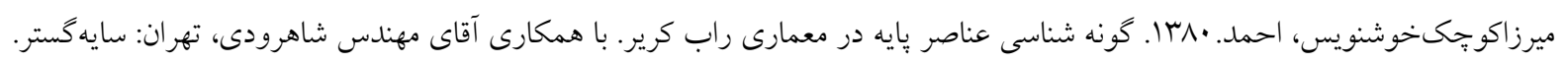

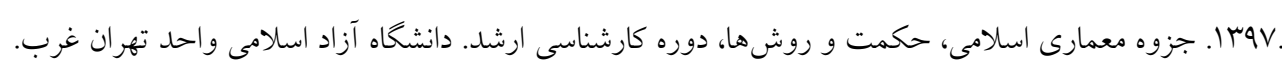

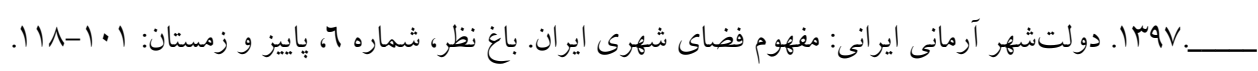
مهدوى نزاد، محمدجواد. شماره19:

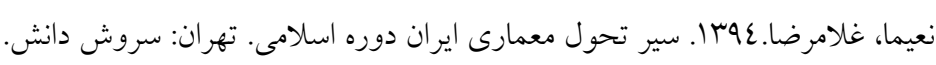

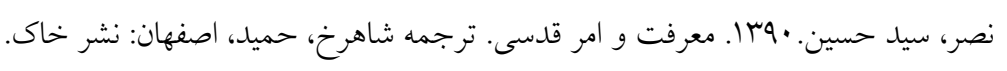

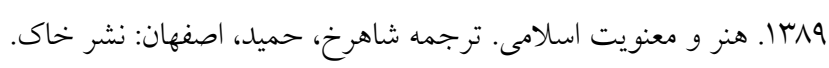




$$
\begin{aligned}
& \text { • • }
\end{aligned}
$$

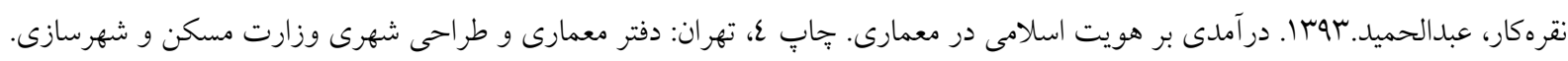

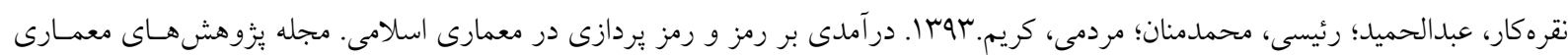

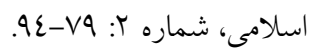

$$
\begin{aligned}
& \text { نقرهكار، عبدالحميد؛ محمد منان رئيسى.بهوبا.تحقق يذيرى هويت اسلامى در آثار معمارى. نشـريه مطالعـات شهـر ايرانى -اسـلامى، شـماره } \\
& .1 Y-0:(V) \\
& \text { هنرفر، لطفاله. • مبا.كنجينه آثار تاريخى اصفهان؛ آثار باستانى و الواح و كتيبهاى تاريخى در استان اصفهان. تهران: جإيخانه زيبا. }
\end{aligned}
$$

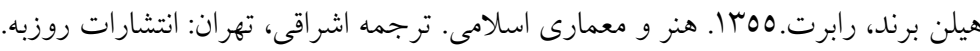

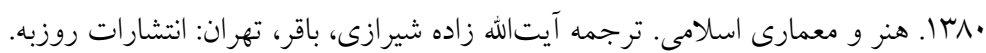

$$
\begin{aligned}
& \text { ياورى، حسين؛ باوفا، رقيه. 0^یז1. اصفهان باغ آسمان، سيرى در حكمت معمارى اسلامى و تزئينات وابسته به آن در دوره صفويه (با تأكيد بـر }
\end{aligned}
$$

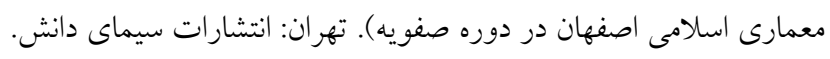

Ahmadi, Mahdieh; Farkish, Hero; Ahmadi, Vahid; Calligrapher, Ahmad Mirza Kuchak. 2020. "Analysis of decoding components of traditional Iranian architecture (a case study of Safavid mosques in Isfahan). Tehran: Arshadan Publications. [in Persian]

Ahri, Zahra; seyed Mohsen Habibi. 2017. «Urban architecture of mosques in Isfahan."Language stories and words." Journal of Safa (26): 3, 22-37. [in Persian]

Akkac ،Samer. 2015. Cosmology \& architecture in premodern Islam: architectural reading mystical ideas. New York: State University of New York Press.P28.

Amir Hosseini, Nikzad. 1954. "History of Isfahan Historical Buildings". First Edition, Publisher: Dad. [in Persian]

Ardalan.N and Bakhtiar.L. 2010. The Sense of Unity, University of Chicago, Chicago.

Avani, Gholamreza. 2013. "Principles of ontology-epistemology, a symbolic view of the world". Quarterly Journal of the Academy of Arts (Imagination 5), 42-53. [in Persian]

Avani, Gholamreza. 2016. "The Wisdom of Spiritual Art". Tehran: Gaross. [in Persian]

---. 2018. "The Wisdom of Islamic Art (its form and meaning in Islamic art and its relationship with art)". Sofe Journal (28): 4, 81-93. [in Persian]

Bean Fisher, William. 1977. "Cambridge History of Iran (20 volumes)". Translated by Ghaderi, Timur, Tehran: Mahtab Publications. [in Persian]

Burckhardt ،Titus and John James.(2010).Chartres and the Birth of the Cathedral.Translated by: William Stoddart.World Wisdom ،Incorporated.P 105.

Burkhart, Titus. 2012. "Sacred Art in the East and the West". Translated by Jalal Sattari, Tehran: Soroush. [in Persian]

---. 2014. "Islamic Art: The Language of Expression". Translated by Massoud Rajabnia, Tehran: Soroush. [in Persian]

---. 2016. "Fundamentals of Islamic Art". Translated by Massoud Rajabnia, Tehran: Soroush. [in Persian]

Chandler, Daniel. 2007. Semiotics: The Basics.London: Routledge, p2.

Ching, Francis D. K.1979.Architecture: Form, Space, and Order, New York: John Wiley \& Sons.

Eismail Nejad, Hussein; Emami, Hamid Reza; Nematollahi, Eiman. 2012. "Typology of mosques in Islamic countries (Iran, Turkey, Spain)". Proceedings of the First National Conference on Geography, Urban Planning and Sustainable Development, Tehran: Koomesh Environmental Association and University of Aviation Industry, April. [in Persian]

Ettinghausen, Richard; Graber, Alg. 1999. "Islamic Art and Architecture". Translated by Azhand, Yaghoub, Tehran: Samt Publications. [in Persian]

Falahat, M.2005.Sense of Place in the Physical Design of Mosques. HONAR-HA-YE-ZIBA, 22 (5), 35-42.

Godard, Andre.1999. "Works of Iran". Translated by Mostafavi, Mohammad Taghi, vol. 2, Publications: Astan Quds[ .in Persian] Grabar, Alg. 2017. "Symbol و Signs in the Interpretation of Islamic Architecture". Translated by Nir Tahoori, Golestan Honar Magazine, No. 2, Tehran: Academy of Arts, 13-25. [in Persian]

Grube, Ernst J. 2011. Architecture of the Islamic World: Its History and Social Meaning, Ed. by George Michell, London: Thames \& Hudson.Hamzehnejad, Mahdi, F. Dadras and N. Hoseini Yekta.2015. Houses' Physical Features based on Temperamental Indicators. Procedia - social and behavioral sciences, 317-324.

Guenon, René. 2002. "The symbolic meanings of the cross." Translated by Partovi, Parvin. [in Persian]

---. 2012. "Article on the symbolic meanings of the dome". Translated by Fardanesh, Farzin, Khayal Quarterly, vol. (4), 72-77. [in Persian]

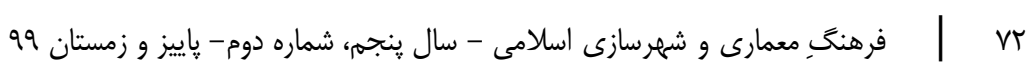


بازشناسى رابطةٌ رمزَان معمارى مساجد و كيفيت حضور قلب نمازگزاران

(مورد يزوهى: مساجد عصر صفوى اصفهان)

Hillenbrand, Robert. 1976. "Book of Islamic Art and Architecture". Ishraqi Translation, Tehran: Roozbeh Publications. [in Persian]

---.1994.Islamic Architecture: Form, Function and Meaning, London: Edinburgh University.

---. 2001. "Book of Islamic Art and Architecture". Translated by Ayatollah Zadeh Shirazi, Baqer, Tehran: Roozbeh Publications. [in Persian]

Hojjat, Jesus; Maleki, Mehdi .2012. "Convergence of three basic geometric types and the emergence of mosque geometry". Architecture and Urban Planning of Fine Arts, Vol.4 . [in Persian]

Honarfar, by the grace of God. 1971. "Treasure of Isfahan historical monuments; "Antiquities and historical tablets and inscriptions in Isfahan province." Tehran, Ziba Printing House. [in Persian]

Jaberi Ansari, Mohammad Hassan. 1999. "History of Isfahan". Edited by Mazaheri, Jamshid, Isfahan: Mashal Publisher, first edition. [in Persian]

Kabir Saber, Mohammad Baqir; Mazaherian, Hamed; Peyravi, Mahnaz .2014. "Architectural Morphology of Kaboud Mosque in Tabriz". Architectural Studies of Iran, Vol. 2, fall and winter, 5-23. [in Persian]

Kabiri Samani, Ali. 2013. "Nature, Architectural Alchemy: A New Look at Man". Nature garchitecture. Isfahan: Goldasteh. [in Persian]

Kanbi, Sheila. 2009. "Safavid Art and Architecture". Movahed Translation, Mazda, Tehran: Institute for Compiling and Publishing Text Works of Art, Second Edition. [in Persian]

Kiani, Mohammad Yousef. 2000. "Architecture of Iran in the Islamic Period". Tehran: Samat Publications. [in Persian]

---. 2016. "History of Iranian Architecture in the Islamic Period". Tehran: Samat Publications, eighth edition. [in Persian]

Kumaraswamy, Ananda. 2017. "Art and Traditional Symbolism". Translated by Alizadeh, Hossein, Tehran: Scientific-Cultural Publications. [in Persian]

Lings Martin. 2016. "The secret and the supreme example". Translated by Massoud Rajabnia, Tehran: Soroush. [in Persian]

Mahdavi Anjad, Mohammad Javad. 2018. "The Wisdom of Islamic Architecture, a search for the deepest spiritual constructions of Iranian Islamic architecture". Journal of Fine Arts. vol. 19, 57-66. [in Persian]

Majidi, Hamid; Zarabadi, Zahra Sadat. 2016. "Essay article on every cognition of symbol, sign of semiotic science". His reference, 49-56. [in Persian]

Majlesi, Mohammad Bagher. 2016. "Baharalanvar", vol. 84, 28. [in Persian]

Martin, Henry, Hogg, John. 2016. "Stylistics of the Art of Architecture in Islamic Lands". Tehran: Scientific and Cultural. [in Persian]

Mazraeh, Hamed.2015."Geometry Analysis in Architecture of Vakil", ICP Engineering and Technology, No. 4, pp. 5-10, December.

Mesbahi, Shokoofeh. 2009. "A Lost of Safavid Art and Architecture". Tehran, Pardaz Media Publishing: Cultural Heritage, Handicrafts and Tourism Organization, Cultural Heritage and Tourism Research Institute. [in Persian]

Mirza Kuchak khoshnevis, Ahmad. 2001. "Typology of the basic elements of water carrier architecture". In collaboration with Engineer Shahroudi, Tehran: Shadow of Gostar. [in Persian]

---. 2019. "The city of the Iranian-Iranian city: the concept of urban space in Iran". Nazar Garden, vol. 6, Fall-Winter, 101-118. [in Persian]

---, Ahmad. 2019. "Booklet of Islamic Architecture, Wisdom and Methods, Master's Degree". Islamic Azad University, West Tehran. [in Persian]

Naeima, Gholamreza. 2015. "The evolution of Iranian architecture in the Islamic period". Tehran: Soroush Danesh. [in Persian]

Nasr, Sayed Hussein. 2001. "Article from Isfahan School to Tehran School". Translated by Manouchehr lynparast, Tehran: Iran, p22. . [in Persian]

---. 2010. "Islamic Art and Spirituality". Translated by Shahrokh, Hamid, Isfahan: Khak Publishing. [in Persian]

---.(2011).Transcendent Philosophy-volume2-number 4-December.

---. 2011. "Knowledge and the Holy Commandment". Translated by Shahrokh, Hamid, Isfahan: Khak Publishing. [in Persian]

Noghreh kar, Abdul Hamid. 2014. "Introduction to Islamic Identity in Architecture". Tehran, Office of Architecture, Design, Urban, Housing Ministry, Urban Planning, 4th edition. [in Persian]

Noghreh kar, Abdul Hamid; Raeisi, Mohammad Manan. 2014. "Realization of Islamic identity in any architectural work". Journal of Iranian-Islamic City Studies, Vol. (7), 5-12. [in Persian]

Noghreh kar, Abdul Hamid; Raeisi, Mohammad Manan; Mardomi, Karim. 2014. "Introductory article on cryptography and cryptography of any Islamic architecture". Journal of Islamic Architectural Research, vol. 2. 79-94. [in Persian]

Parsania, Hamid. 2014. "Symbol of myth". Qom: Asra Publishing Center. [in Persian ]

Pope, Arthur Opham; Ackerman, Phyllis .2008. "Siri in Iranian art". Translated by Daryabandari, Najaf et al., Tehran: Scientific and Cultural Publications. [in Persian]

Prochazka, Amjad Bohumil. 1986. Architecture of the Islamic Cultural Sphere, Zurich: MARP. Rezazade, R.2004.The Role of Architecture in Revealing Meaning and Concepts. Mosque Architecture: Traditional or Innovative. HONAR-HA-YE-ZIBA. $18,37-48$.

Rabban Shah, Leila; Sultanzadeh, Hossein; Ghadiri, Bahram.1996. "Typology of mosque architecture". Tehran: Cultural Research Office. [in Persian] 
Rafiei Mehrabadi, Abolghasem. 1973. "National Works of Isfahan". Tehran: Etihad Printing House. [in Persian]

Shayesteh Far, Mahnaz. 2005. "The decorative role and message of the inscription in Islamic architecture". Book of the Moon and Art, vol.3, 89-90. [in Persian]

Stringers, Hope; Bell, Simon. 2010. "Applied knowledge of space layout in understanding the spatial configuration of cities." Journal of Fine Arts - Architecture and Urbanism, Vol43, 49-56. [in Persian]

The Holy Quran, Surah Al-Baqarah, verse 261; And Surah Al- Noor, verse 31; And Surah Al-Room, verses17 and18. [in Persian]

Tonna, Jo.(2010).the Poetics of Arab-Islamic Architecture.In Muqarnas VII: An Annual on Islamic Art and Architecture, edited by Oleg Grabar.Leiden: E.J.Brill, pp 182-197.

Turkmen Khameh, Iskandar Bey. 2003. "The World of Abbasi Opinions". Edited by Afshar, Iraj, Tehran: Amirkabir Publications. [in Persian]

Yavari, Hussein; Bafa, Roghayeh2006. "Isfahan Garden of Heaven, a look at the wisdom of Islamic architecture and related decorations in the Safavid period (with emphasis on the Islamic architecture of Isfahan in the Safavid period)". Tehran: Simaye Danesh Publications. [in Persian]

Zarei, Mohammad Ibrahim. 2010. "Iranian Architecture from the Safavid Era to the Present Era". Tehran: Samat Publications. [in Persian]

---. 2015. "Typology of the architecture of neighborhood mosques in Sanandaj during the Qajar period". Studies of the Islamic Iranian city, vol. 6, spring. [in Persian]

Zeymaran, Mohamad.2014."Introduction to the semiotics of art". Tehran: Story Publishing. [in Persian] 